Discussion Paper No. 687

\title{
ATTITUDES TOWARD THE INCOME GAP: \\ JAPAN-U.S. COMPARISON
}

\author{
Fumio Ohtake \\ and \\ Shinji Takenaka
}

\begin{abstract}
April 2007
The Institute of Social and Economic Research Osaka University

6-1 Mihogaoka, Ibaraki, Osaka 567-0047, Japan
\end{abstract}




\title{
Attitudes toward the Income Gap: Japan-U.S. Comparison ${ }^{*}$
}

\author{
Fumio Ohtake, Osaka University ${ }^{\dagger}$ \\ Shinji Takenaka, Osaka University*
}

\begin{abstract}
Employing the Japan-U.S. international survey, this study analyzed the cause of rising perception of the widening income gap in Japan. Between these two countries, their distinct value judgments on the substance of gap influence their recognition. Japanese have negative perception of the income gap caused by talent, academic background or luck; it seems relatively weak in the U.S. A large portion of Japanese also think one's income is recently decided by talent, academic background or luck though it should not be. Such disagreement between the desirable and recognized determinants of income is thought to raise their perception of the gap.
\end{abstract}

\section{Introduction}

From the year 2005 through 2006, expansion of the income gap received large public attention in Japan. Some of the Japanese best sellers in 2005 addressed a classed society. The issue of gap in society was also debated in the Diet in 2006. The debates stemmed from not only political backgrounds, including the argument about a series of recent structural reforms or the upcoming presidential election of a ruling party, but also the rising perception of economic inequality among Japanese. In fact, according to the results of National Survey on Lifestyle Preferences (conducted by the Cabinet Office, Government of Japan) since the 1980's, an increasing percentage of people thought that their preference for low inequality of income and property has been almost unsatisfied. The percentage reached a quarter of the whole in the 2005 survey. Parallel to the increase in such public concern, the income gap in Japan has actually continued to rise since the end of the 1970's, as shown in Figure 1.

Why has the income gap in Japan continued to expand? Discussing the issue

\footnotetext{
* The authors are indebted to Kiyoshi Ota for his comments on an earlier version of this paper.

† Institute of Social and Economic Research

$\$$ Graduate School of Economics
} 
thoroughly, Ohtake (2005) states that a large part of the continuing income gap expansion can be explained by the ageing of population. The gap within each age group, except recent twenties, has remained unchanged in Japan. Income inequality, on the whole, has nevertheless been widened by the ageing of the Japanese population. The income gap has been greater within the older group in Japan. Such a lifelong gap starts widening around the age of forty, when the speed of promotion begins to differ among employees. Japanese ageing has thus enlarged the groups of larger income gap and increased inequality. On the one hand, the income gap among the younger generation rose from the end of the 1990's through the beginning of the 2000's. This recent trend was caused by the rapid increase of freelancers and the unemployed in their seriously bleak employment situation. Another characteristic observed since the late 1990's is the decrease in wages earned by the low-wage group of male workers.

As explained above, the widening gap in the flow of income can be explained by the population's ageing. The gap in lifetime income could, however, have widened even if the within-group gap had hardly changed. Less frequent movements across income classes would result in a wider gap in lifetime income, even if the gap were unchanged within each age group. The widening of the gap between assets would also yield the same effect. In fact, the gap in consumption, which is a proxy of lifetime income inequality, tends to widen among the age groups under fifties (Ohtake, 2005).

Although the Japanese long-term trend of the income gap stems from the ageing of the population, the upward tendency of the income gap has never been a unique observation in Japan. As is well known, the U.S. income gap has also shown its tendency to expand (Figure 1). In fact, the cause of such expansion has been one of the big issues among economists since the 1980's ${ }^{1}$. Among the studies in the United States, many of them have addressed the skill-biased technical change (SBTC) and the globalization of economy as the potential causes of the widening income gap. These studies concluded the following two reasons are responsible for the expansion of the income gap in the 1980 's. First, the technological progress had been biased in favor of the labor demand for highly educated or high-skilled workers. Second, the

\footnotetext{
${ }^{1}$ For instance, see Katz and Autor (1999).
} 
globalization of economy had decreased the labor demand for lower-educated workers in developed countries.

The U.S. upward trend after the 1990's is, by comparison, recently characterized by the rapid income growth of high-income earners and highly educated workers and by the within-group income dispersion among the highly educated group ${ }^{2}$. According to Piketty and Saez (2006), the income share of the top $0.1 \%$ in the U.S. used to be around two percent from the 1960's to 1970's; on the other hand, the share exceeded seven percent in 2000. The growth of their income share is, in addition, accounted for by the increase in salaries instead of capital income. Such increase in the income concentration is commonly observed in the English-speaking countries, including the United Kingdom and Canada. In contrast, the income share of high-income earners in Japan and France has been stable at around two percent since the Second World War. The trend is unchanged since $2000^{3}$. Decomposing the U.S. recent wage inequality, Lemieux (2006) also shows that the wage for the highly educated group has increased and their within-group wage dispersion has widened during the same period of time. Besides, Autor et al. (2006) suggest that the computerization of work has brought about the polarization of wage distribution in the U.S.

Piketty and Saez (2006) and Autor et al. (2006) furthermore provide the following reasons for the recent increase in income inequality in the U.S. First, the routine tasks of white-collar workers have been replaced by computers; consequently, jobs have been polarized into manual tasks and high-skilled work beyond the reach of computerization. Second, the economic globalization initiated the unskilled labor-intensive exports of the developing countries to the developed ones, while computerization has allowed a part of white-collar jobs to be transferred from developed countries to developing ones. Third, because of such technological progress, the required skills of executives have become more general, industry-wide

\footnotetext{
2 See Autor et al. (2006), Lemieux (2006) and Piketty and Saez (2006).

3 The research on the Japanese trend is based on Moriguchi and Saez (2006). Their study analyzed the data up to the year 2002; thus, the top-income share in Japan did not increased until then at least.
} 
rather than firm-specific; therefore, the enlarged labor market of executives has produced a group of superstars, similar to the ones of singers and professional athletes, among these business elite.

The widening income gap in the U.S. has never been a political issue, although the gap has shown rapid expansion. The Japanese income gap is, by contrast, now the subject of political debate, whereas the income-gap expansion, excluding the part driven by ageing of the population, is small-scale ${ }^{4}$. Why do attitudes differ between Japan and the U.S.?

Employing the Japan-U.S. comparative survey data of Osaka University 21 st Century Center of Excellence Program (February 2006), this research will examine the issue of income inequality as follows. First, this article will describe the difference in the recognition of the income gap and the different attitudes toward redistributive policies between Japan and the United States. Second, it will examine whether risk aversion parameter and altruism, supposed to be critical from an economic viewpoint, can actually explain attitudes toward the income gap. Third, it will clarify how the values in determinants of the income gap differ between the two countries. Forth, it will also examine whether those beliefs relate to the recognition of a widening gap in income.

\section{The Recognition of the Income Gap: Japan-U.S. Comparison \\ Data}

This paper's analysis will be based on the data from two questionnaire surveys: (1) Osaka University 21st Century Center of Excellence Panel Survey [conducted in Japan] (OPSJ) and (2) Osaka University 21st Century Center of Excellence Panel Survey [conducted in the USA] (OPSUS). Their basic information is described below.

Both surveys contain hypothetical questions to measure a respondent's risk aversion and altruistic attitude, as well as the individual attributes including

\footnotetext{
${ }^{4}$ The Economist issued on June 16, 2006 also featured the low public interest in the income-gap expansion in the U.S. and the increasing attention to the same issue in Japan.
} 
educational attainment, age and income. The principal questions used for this research are reproduced in Appendix 1.

OPSJ is a panel study begun in February 2004 as part of the Osaka University 21 st Century Center of Excellence Program. The survey has been conducted annually since 2004 using a random sample drawn from 6,000 individuals by a placement (self-administered) method. It had 4,224 and 2,987 respondents in 2004 and 2005, respectively. Excluding 108 individuals lost from the last 2,987 respondents, 2,000 new random-sampled individuals were added to the survey sample in 2006. The 2006 survey was then distributed to 4,879 individuals and the number of respondents was 3,763 . Its response rate was $77.1 \%$, while the figure equals $47.1 \%$ for the total 8,000 individuals included in any samples. This research will use the survey questions about the recognition of the income gap, which were included only in the 2006 survey.

OPSUS is also administered as part of the Osaka University 21 st Century Center of Excellence Program. This mail survey was conducted with 12,338 individuals in January and February 2005. The number of respondents was 4,979. Another survey was mailed to respondents of the 2005, with 3,120 responses being obtained in January and February 2006. The response rate in 2006 is equal to $25.3 \%$ for all 12,338 individuals in either sample or both. All the questions were the same as those in each OPSJ survey.

\section{The Japan-U.S. difference in the recognition of the income gap}

In each country, the survey inquires about the respondents' thought on changes in the following domestic gaps for the last and the next five years: (1) the gap between income or earnings, (2) the one between assets such as savings, stocks, land and housing, (3) the income gap due to differences between families which one grew up in, and (4) the gap between spending standards (Question 44 and Question 45). The questionnaire also asks about whether he or she considers the current expansion of the income gap as problematic (Question 46) and about the enforcement of redistributive policies (Question 47).

Using the responses to these questions, the Japan-U.S. difference in the 
recognition of the income gap and in their attitudes toward to it will be examined. Figure 2 shows the percentage of those who recognize or expect the expansion of gaps between income or earnings, assets, and spending in the last or next five years. In the U.S., the figures are between 50 and 60 percent for the three kinds of gaps. The gaps of income and assets in Japan are, in contrast, recognized by 68 and 60 percent of the respondents respectively. It is also characteristic of the Japanese responses that the percentage is larger for those expecting the future expansion of gaps than for the people having recognition of such expansion in the last five years.

The proportion of those who agree with the enforcement of income redistribution from the rich to the poor (using the taxation system and social security policy) are $51.7 \%$ and $45.3 \%$ in Japan and the U.S. respectively. The Japanese percentage is significantly greater than its U.S. counterpart (Figure 3). The larger percentage of the support for redistribution in Japan cannot be attributed to the Japanese higher portion of those considering the widening income gap as problematic. In both Japan and the U.S., approximately 73 percent of respondents view the gaps as problems, yielding no significant difference between the percentages statistically. Thus, the different thoughts on the necessity of enforcing redistribution between the two states cannot be caused by the difference in their values viewing the income-gap expansion, but by their contrasting recognition of the enlarging income gaps.

\section{Thoughts on the income gap by income groups}

For higher income groups, a larger share of people recognizes and expects the expansion of the income gap (Figure 4,5). The positions of income groups arranged in order of the income-gap recognition are, interestingly, different to the one in order of the share of individuals viewing the gap as problematic. In both Japan and the U.S., the portion of people considering the income-gap expansion as unproblematic is greater for higher income groups. In addition, the share of those who support the enforcement of redistribution policy is higher for lower income groups.

\section{Thoughts on the income gap by age groups}


Observing the recognition of the income gap by each age group of Japan, the rate of recognition among the forties and fifties is higher than the others' (Figure 6). In addition, the age groups from forties to sixties bear the larger shares of those viewing the gap as problematic. In contrast, the portion of individuals viewing the income gap as problematic is the lowest in the group in their 20 s than others, while the within-group gap in income and earnings among the twenties has been observed widening in actual data. The support for redistributive policies is relatively high for the groups aged fifty or over in Japan.

In the United States, the rate of income-gap recognition is comparatively high in the age groups in their $20 \mathrm{~s}$ and $50 \mathrm{~s}$, while the share of those expecting the gap to widen is higher in the age groups less than 60 (Figure 7). On the other hand, the share of people viewing the income gap as problematic is larger in the groups aged fifty or older. The U.S. share of those supporting the enforcement of redistributive policies is high among the age groups in their $20 \mathrm{~s}$.

\section{Thoughts on the income gap by genders}

Comparing the share of those recognizing the widening income gap and that of those expecting a future expansion of the gap, men bear larger percentages for those two points than women in Japan and the U.S (Figure 8, 9). On the one hand, the portion of females viewing the income gap as problematic is higher than males. On the other hand, the share of males supporting the enforcement of income redistribution is larger than females in Japan, probably because a smaller percentage of women recognize the widening income gap than men.

\section{Determinants of Thoughts on the Income Gap: Regression Analyses}

This section will relate the people's recognition of a widening income gap and their views on it to their individual attributes, basing the relations on the results of the following regression analyses. Employing Japanese data in 2002, Tomioka and Ohtake (2005) found that those who recognize the expansion of the income gap were composed of females, middle aged, or highly educated people and those expecting the 
unemployment of their family members or themselves. The enforcement of redistributive policies was supported by those aged fifty or older, expecting their unemployment, being risk averse or categorized as low-income individuals. Do we find the same result from the Japan-U.S. international survey in 2006 for this comparative study?

\section{Determinants of support for redistribution}

The economic determinants of support for redistributive policies will be briefly laid out ${ }^{5}$. Within a static framework, a lower-income class, supposed to benefit more, is expected to agree with the redistribution, whereas a higher-income class, incurring a heavier burden, is predicted to oppose such policies. The preceding studies have actually proved the negative correlation between income level and the support for redistribution.

However, if there exists mobility across income classes in the future, current income is not the sole determinant of support for redistribution today. Benabou and Ok (2001) theoretically pointed out the possibility that low-income people, considering their potential of becoming rich, do not support redistribution in a society with high mobility across income classes. They call that hypothesis the "Prospect of Upward Mobility" (POUM) Hypothesis. The high-income class may, on the other hand, support redistributive policies. Such attitudes conform to economic rationality, if the current rich predict the possibility of decline in their future income.

The empirical studies on the above issue include Alesina and La Ferrara (2005), which constructed an index of income mobility using the Panel Study of Income Dynamics (PSID) and found a negative correlation between the mobility and the individual support for redistribution. Using a data set from Russia, Ravallion and Lokshin (2000) argue that those expecting a decline in their welfare tend to support the equalization of individual income levels. They said that such tendency applies even to the current high-income group. Ohtake and Tomioka (2004), using Japanese data, showed that the supporters of redistribution in Japan comprise those expecting a

\footnotetext{
${ }^{5}$ See Ohtake (2005) or Ohtake and Tomioka (2004) for detailed discussion.
} 
decrease in their income through unemployment and those having the experience of a decline in their consumption level.

If the POUM hypothesis is correct and people expect their mobility across income classes, present low-income earners will not necessarily support the redistribution. If the prospect of moving up the income ladder decreases beyond a certain level of age, holding others constant, the aging should make individuals become more inclined to support the redistribution. Conforming to this hypothesis, the result of Ohtake and Tomioka (2004) indicated that older age groups are more likely to support redistribution in Japan. Alesina and La Ferrara (2005), on the other hand, found that aging led people to be more reluctant to support redistribution in the U.S.

The important determinants of support for redistribution contain not only the economic environment like income classes and the mobility across those classes but also the individual preferences including attitudes toward risk and altruism. Risk averse individuals are, for instance, thought to be likely to support redistribution working as a safety net. Many empirical studies have used a self-employed dummy as an inverse proxy for risk aversion. When individual support for redistribution was a dependent variable in Alesina and La Ferrara (2005), the coefficient of the self-employment dummy was estimated to be significantly negative, which means the self-employed tend to oppose redistribution. The validity of that proxy, however, remains debatable. Ohtake and Tomioka (2004), in contrast, developed an alternative: the lowest percentage of rainfall in a weather forecast which makes respondents take umbrellas with them when going out. Using the alternative variable, they found that people became more likely to support redistributive policies, as they were more risk averse. In addition, high-income earners, incurring net loss from such policies, are also thought to support redistribution when they are sufficiently altruistic.

\section{Indices of risk aversion and altruism}

(Risk aversion)

This article employs two distinct indices of risk aversion. Each of them is 
based on the responses to a different question. One of the indices equals one minus the lowest percentage of rainfall that makes the respondent take an umbrella with him when going out, as used in Ohtake and Tomioka (2004). Specifically, the responses are obtained from Question 18, asking, "When you usually go out, how high does the probability of rain have to be before you take an umbrella?" ${ }^{6}$ The other is the estimate of constant relative risk aversion (CRRA) parameter, derived from the responses to a set of hypothetical questions asking about respondents' preferable ways of receiving monthly income. See Appendix 2 for the estimation method.

\section{(Altruism)}

A dummy variable serves as the index of altruism. The variable is based on the responses to Question 27 and 28, asking about the respondents' will to donate to a charity giving financial help to the poor. That variable takes one if respondents showed their will to donate non-zero amounts of their family income in either of the following two hypothetical cases: (1) the donation would be handed to the poor directly, or (2) the charity would give twice the amount of their donation to the beneficiaries $^{7}$.

\section{Estimation results}

The four probit models, each adopting (1) Recognition of gap expansion, (2) Expectation of gap expansion, (3) Viewing the gap as problematic, and (4) Support for

\footnotetext{
${ }^{6}$ Ohtake and Tomioka (2004), by contrast, used the question asking, "When you usually go out, how high does the probability of rain in a weather forecast have to be before you take an umbrella?" Any index derived from that question cannot distinguish the bias caused by respondents' optimistic or pessimistic expectation of rain, or the effect of subjective evaluation of the forecasted probability, and the attitudes toward the objective probability of rain, classically regarded as risk aversion. The question used in this analysis, on the other hand, can separate the influence of such optimistic or pessimistic expectation from the risk preference.

7 The indexes of risk aversion and altruism may bear measurement errors because the respondents could have failed to answer the questions accurately. Such errors would bias the coefficient of those indexes toward zero when they are employed as explanatory variables in an empirical analysis. Thus, this study also conducted the estimation with the mean values of indices measuring risk preference and altruism for the respondents of the same question in both the 2005 and 2006 surveys. The result of analysis basically remained unchanged from the counterpart based solely on the 2006 survey; thus, the following part of this paper will show the estimation employing only the 2006 survey.
} 
redistribution as their dependent variables, were estimated for explaining (1) (4) by individual attributes and the indexes of risk preference and altruism. Recognition of gap expansion is the dummy variable, taking unity if a respondent recognizes the expansion of a gap between income or earnings in the last five years; it otherwise equals zero (Question 44). Expectation of gap expansion is similarly the variable to equal one if a respondent expects the income gap to expand in the next five years (Question 45). Viewing the gap as problematic is, in addition, defined as the dummy variable to take unity if a respondent thinks the expansion of income or earnings is problematic (Question 46); Support for redistribution is also the binary variable to equal one if respondents agree with the enforcement of redistributive policies (Question 47-1).

Each estimation employed either of the two indexes of risk preference: the one based on probability of rain or the estimated CRRA coefficient. Concerning the results with the former index of risk preference, the estimated marginal effects of explanatory variables are shown in Appendix 4. Those effects are also depicted in Figures 10 and $11^{8}$.

\section{(Estimation results for Japan)}

The results from Japanese data are examined as follows (Figure 10). While the various individual attributes are controlled, the greater portion of the $40 \mathrm{~s}$ and $50 \mathrm{~s}$ has the recognition and the expectation of a widening gap between income or earnings than that of $20 \mathrm{~s}$. Concerning whether they view its expansion as problematic or not, however, no significant difference in opinion was found among all the age groups. The support for redistribution is greater in older age groups. The graduates (and those who have a postgraduate diploma) are more likely to recognize and expect the expansion of the income gap and are inclined to agree with redistributive policies.

\footnotetext{
${ }^{8}$ The correlation coefficient of the CRRA parameter and the index based on the probability of rain is 0.028 for the Japanese sample; the counterpart of the U.S. equals -0.02 . Neither is statistically significant. If there is any difference in the estimation results by the choice of risk preference parameter, it will be noted hereafter. The correlation between the risk aversion measured by the probability of precipitation and the altruism index is, in contrast, significantly positive for Japan and the U.S.
} 
High-income earners tend to recognize the gap expansion and are less likely to view it as problematic than low-income individuals. The high-income groups are also less likely to agree with the enforcement of redistribution. Comparing the results by gender, it can be found that men are more likely to recognize the expansion of the income gap and support the enforcement of redistribution than women. Although women are more apt to view the gap as problematic, they are less likely to recognize its expansion than men. These tendencies can be interpreted as the reason why females are less inclined to support the enforcement of redistribution than males. In addition, those who expect the unemployment of their family members or themselves tend to recognize the gap's expansion, view it as problematic and agree with redistribution. Moreover, the risk aversion parameter, measured by the lowest percentage of rainfall that makes one take an umbrella, shows no significant effect in all the estimation models statistically. Though the results are omitted, the increase in the CRRA coefficient decreases the recognition of income-gap expansion. The CRRA estimates, however, show no significant effects on the value judgment on its expansion and the support for redistributive policies. Furthermore, the altruistic respondents are more likely to regard the expansion as a problem and to agree with the enforcement of redistribution.

Among the above results, the effect of risk aversion parameter differs from the counterpart in Tomioka and Ohtake (2005) and Ohtake and Tomioka (2004). That parameter has shown its positive effects on the recognition of the gap expansion, viewing the gap as problematic and the support for redistributive policies. As noted in footnote 6 , the risk aversion index employed in these previous studies could have also absorbed the pessimistic expectation of the future. This study's index, by contrast, separated such pessimism from the risk preference itself. The pessimistic Japanese, rather than risk-averse ones, should thus be more likely to recognize the expansion of the gap between income or earnings and agree with the enforcement of redistributive policies.

(Estimation results for the U.S.) 
Referring to Figure 11, the estimation results from the U.S. sample are next examined and compared to their Japanese counterparts. Compared to the results for Japan, a distinction can be found in the non-existence of a large difference by age with regard to the recognition of income-gap expansion and the value judgment on it in the U.S. In addition, the probability of agreeing with the enforcement of redistribution is significantly lower in the age group of the seventies and over. Moreover, the highly educated group is more likely to recognize the expansion of the income gap. It is consistent with the recent U.S. income-gap trend characterized with the more rapid expansion of within-group wage inequality for the highly educated group than for the others (Lemieux, 2006). On the one hand, whether they recognize the expansion of the gap between income or earnings does not significantly differ by income groups. On the other hand, the portion of people viewing the income gap as problematic or supporting redistribution is lower for higher income groups. Similar to the Japanese case, those who expect the unemployment of their family members or themselves are more likely to recognize the expansion of the gap and view it as problematic. Furthermore, those who experienced an increase in their consumption expenditure are inclined to expect the future expansion of the gap, regard the gap as a problem and agree with redistributive policies. If the increase in consumption reflected the future income growth, the above result would disagree with the POUM hypothesis. That result would rather show the effect of an unexpected shock to increase consumption while the income remained constant. Unlike the result for the Japanese, more risk averse people in the U.S. are likely to support the enforcement of redistribution. Besides, the altruistic U.S. citizens are significantly more apt to recognize the gap, view it as problematic and agree with the enforcement of redistributive policies.

The estimation results for these two countries can be summarized as follows. First, the highly educated group and those having the expectation of unemployment tend to recognize the expansion of the income gap. In addition, altruistic people and low-income earners are likely to support redistributive policies. These findings are obtained in both Japan and the U.S. Second, the middle-aged Japanese are more likely 
to recognize the expansion of the gap, while redistributive policies get greater support from older groups. In the U.S., by contrast, there is no significant difference in the recognition of the gap by age groups while the elderly tend to avoid supporting the enforcement of redistribution.

A characteristic finding in both Japan and the U.S. suggests that the highly educated or high-income group, showing greater recognition of the expansion of the income gap, neither view that expansion as problematic nor expect the enforcement of redistributive policies. Moreover, the group of people regarding the expansion as a problem does not necessarily agree with the enforcement of redistribution, because a part of them failed to recognize the widening gap itself. This is exemplified by the tendency observed in Japanese women. They are less likely to support redistribution than Japanese men are, whereas a greater portion of them considers the expansion of the gap as a problem than the males. The Japan-U.S. difference in their support for redistributive policies can be also attributed to the contrasting levels of recognizing their own expanded gaps in these countries.

\section{Recognition of Income Determination}

The preceding section found that the Japan-U.S. difference in recognizing the expansion of income gap affected their attitudes toward the redistributive policies. This section will examine the possibility that their values in desirable determinants of the income gap affect their recognition. Based on the responses to the question asking about how people's incomes are decided (Question 42), Figure 12 shows the share of respondents who think income is decided by a particular factor. For both Japan and the U.S., the proportion of those who think one's choice or effort decides his or her income is higher than the counterparts of any other factors: $68 \%$ in Japan and $84 \%$ in the U.S. The share of people having the opinion that one's luck on occasions decides his or her income barely differs between Japan and the U.S.

These two countries, however, show clear contrasts when we make a comparison of the proportions of those who think inborn talent or academic background decides their income. One's academic background is thought to be a 
determinant of income by $77 \%$ of the U.S. residents; on the other hand, the proportion equals only $43 \%$ for Japanese. Similarly, those who think “one's inborn talent decides income" amounts to $60 \%$ in the U.S.; in contrast, only $29 \%$ of Japanese agree with the idea. The three most major determinants of income are, in descending order, (1) choice or effort, (2) academic background, and (3) inborn talent for the U.S.; in contrast, the counterparts for Japan are (1) choice or effort, (2) luck on occasions and (3) academic background.

When thoughts on income gap are compared between Japan and the U.S., values in "what should decide one's income" show greater international differences. Among the determinants in Figure 13, "choice and effort" collects the largest support in both Japan and the U.S. However, the proportion of those who think that academic background or inborn talent should decide income exceeds $50 \%$ in the U.S., whereas each corresponding share in Japan ranges from 10 to 15 percent only. Japanese thus have negative perception of other factors than choice or effort as determinants of income. The residents in the U.S., on the other hand, tend to tolerate the income gap caused by the difference in one's inborn talent or academic background.

Is there any age difference in their value judgments on income determination? On each age group, Table 1 shows the proportion of those who support the factors in the first row as desirable determinants of income. Except for the people in their 70s or over, no large difference in their value judgments on those determinants can be found among the U.S. age groups. The Japanese, by contrast, show large age differences in their values. Especially, the proportion of those who think luck on occasions should decide one's income is greater in the age groups under 40 than the others. In addition, the people who regard inborn talent as a desirable determinant of income occupy a greater share in younger age groups in Japan. Moreover, the larger proportions of those recognizing the income-gap expansion, observed in the age groups from the $40 \mathrm{~s}$ to $60 \mathrm{~s}$, reflect their greater tendency to dislike the income being decided by luck on occasions ${ }^{9}$.

\footnotetext{
9 The inferences made by the results of this simple tabulation are qualitatively the same as those obtained from multiple probit analyses.
} 
The disagreement between values in what should decide people's income and the recognition of how one's income is decided may form their impression of the widening gap. Such a possibility will be now examined. The recognition of an expanded gap between income or earnings is, in Japan, more frequently observed among those having disagreements between the desirable and recognized determinants of income gap than the others. The disagreements are classified as follows (Table 2); (1) one's income is decided by inborn talent, though it should not be, (2) one's income is decided by their academic background, although it should not be, (3) one's income is decided by luck on occasions, whereas it should not be, and (4) one's income is decided by their family environment, although it should not be.

A clear Japan-U.S. difference can be found in values and recognition concerning people's academic background and income. The proportion of those who think that people's income is decided by their academic background though it should not be gains a majority of Japanese, $52.3 \%$. The percentage of such group in the U.S. is only $21.2 \%$. Among such group, the proportion of those recognizing past income-gap expansion is high in Japan. The same tendency cannot, however, be observed in the U.S. Hence, the recognition of the income gap in Japan partially stems from their recognition of a widening gap caused by inborn talent, luck, academic background and family environment rather than choice or effort. The percentage of those thinking that one's income is decided by their family environment though it should not be, however, bears only a small difference between Japan and the U.S.

The Japan-U.S. difference in recognizing equal opportunities

The analysis above found a large Japan-U.S. difference in value judgment on the effect of inborn talent and academic background on income. Contrary to expectation, however, the residents in Japan and the U.S. have similar values in other social and economic factors concerning the income gap, as shown in Table 3. In both countries, for instance, approximately $20 \%$ of them agree with the opinion that society should have a wide enough income gap for encouraging one's willingness to work. 
Those percentages are relatively low in the table. Similarly, no large Japan-U.S. difference is observed concerning the proportion of those who agree with the following ideas: (1) equal opportunity of becoming rich should be given by society; (2) there should be a society where everyone can gain enough income for a minimum standard of living if he or she works diligently; (3) our society should give enough help to people who are so poor and have difficulties in living. Comparing the proportions between the two countries, Japan has higher percentages of agreement with the first two opinions above. The percentage for the third idea is, in contrast, greater in the U.S. than Japan.

Recognition of the income gap at present, on the other hand, shows a large difference between Japan and the U.S. (Table 3). The most evident contrast is observed in the proportion of those supporting the opinion that equal opportunity of becoming rich is given by society even though one is poor at present. The percentage amounts to $15 \%$ in Japan, whereas the figure equals $43 \%$ in the U.S. A large majority of Japanese, in other words, believe that opportunities are not equal. Comparing among the age groups, the share of those supporting the idea of equal opportunities is higher for the groups of 50-plus than the younger in both Japan and the U.S. (Table 4). A large Japan-U.S. gap can be also found in the percentage of those agreeing with the opinion that their society is giving enough help to people who are so poor and have difficulties in living. That percentage equals $13 \%$ in Japan; the figure is $38 \%$ in the U.S.

\section{Concluding remarks}

Employing the data based on identical survey questions in Japan and the U.S., this study empirically analyzed the cause of rising perception of the widening income gap in Japan. The statistical indices show that the income gap has been greater in the U.S. than in Japan. A greater percentage of Japanese, however, recognizes or expects the widening income gap, compared to U.S. citizens. Between these countries, there is, nevertheless, no large difference in the proportion of those who regard their expanded gap as problematic or support the enforcement of redistributive policies. The 
difference in their recognition and expectation is attributed to their distinct value judgments on the substance of the income gap. The Japanese, in particular, have a strongly negative perception of the expansion of the income gap caused by talent, academic background or luck, whereas such perception seems relatively weak in the U.S. A large portion of Japanese recognizes that one's income is recently decided by his or her inborn talent, academic background or luck on occasions although they generally dislike their income being decided by any factors other than choice or effort. Such disagreement between the desirable and recognized determinants of income is thought to have raised the Japanese perception of the gap during recent years. Besides, the percentage of those who believe equal opportunities for becoming rich is very low in Japan.

The expansion of the income gap tends to be recognized by highly educated people or high-income earners in both Japan and the U.S. However, these groups of people are neither likely to view the income gap as problematic nor inclined to agree with the enforcement of redistributive policies. That is, the people recognizing the expansion of the income gap do not necessarily support redistribution. Altruistic people, in addition, tend to have negative perception of the increase in the income gap and support redistributive policies. Altruistic U.S. residents are also apt to recognize the income gap expansion.

An evident difference is observed in the effect of age. In Japan, people of middle age, in their forties or fifties, are likely to recognize the widening gap, while support for redistributive policies is stronger for higher age categories. In contrast, the portion of people recognizing the expansion of the gap does not differ by age in the U.S; besides, those aged seventy or over are more likely to oppose the enforcement of redistributive policies.

Summarizing the possible causes of the rising perception of the gap in Japan, the greater portion of Japanese recognize that their income has become more likely to be decided by luck on occasions, academic career or inborn talent, although they consider such change as undesirable at the same time. In addition, recognition of the expanding income gap is largely affected by their countries or ages, for the 
differences in those attributes cause a large distinction of their values in what should decide one's income.

Altogether, people are thought to recognize the gap between their incomes as they have begun to be decided by morally undesirable factors. In other words, they seem unlikely to react just to the rising index of income inequality including its Gini index or variance. From the latter half of the 1990's, the traditional seniority-oriented wage system in Japan has begun to adopt a performance-based salary, decided by not only their effort but also their luck or talent. The traditional system, in contrast, used to be mainly based on the evaluation of the length of an employee's overtime work and his or her effort. The recent change in income determination, becoming estranged from their traditional values, is thus thought to cause the increased perception of the widening income gap among the Japanese.

The perceived level of the income gap in Japan should be higher than the level indicated by the statistical data, for the Japanese think that the gap has been widened by unacceptable causes including one's talent, luck, and academic background, rather than the desirable ones like choice or effort. In addition, the average executive salary in Japan has never reached the level of its counterpart in the U.S., maybe because Japanese society has a social norm placing great emphasis on effort. The people living in the U.S. are comparatively unlikely to perceive the gap expansion, even though it has actually continued to expand. They tolerate the gaps caused by one's academic background and inborn talent; they also believe that equal opportunity of becoming rich is given by their society. It is thus inferred that such international division of thoughts can explain the Japan-U.S. difference between their attitudes toward the income gap in each country. 


\section{References}

Alesina, Alberto. and Eliana La Ferrara (2005), "Preferences for Redistribution in the Land of Opportunities", Journal of Public Economics, vol.89, 897-931.

Autor, David H., Lawrence F. Katz, and Melissa S. Kearney (2006), “The Polarization of the U.S. Labor Market", American Economic Review, vol.96, no.2, 189-194.

Benabou, A. and E. Ok (2001), "Social Mobility and the Demand for Redistribution", Quarterly Journal of Economics, vol. 116, pp. 447-487.

Katz, Laurence. F. and David. H. Autor (1999), "Changes in the Wage Structure and Earning Inequality", in Orley Ashenfelter and David Card (eds), Handbook of Labor Economics, vol.3A, Amsterdam: North-Holland, pp. 1463-1555.

Kimball, Miles S., Claudia R. Sahm. and Matthew D. Shapiro (2005), "Using survey-based risk tolerance", unpublished, Michigan University.

Lemieux, Thomas (2006), "Postsecondary Education and Increasing Wage Inequality", American Economic Review, vol.96, no.2, pp. 195-199.

Moriguchi, Chiaki and Emmanuel Saez (2005), "The Evolution of Income Concentration in. Japan, 1885-2002, Evidence from Income Tax Statistics", mimeo.

Ohtake, Fumio (2005), Nihon no Fubyodo (Inequality in Japan) (in Japanese), Tokyo: Nihon Keizai Shinbunsha.

Ohtake, Fumio and Jun Tomioka (2004), “Who Supports Redistribution?”, Japanese Economic Review, vol.55, pp. 333-478.

Piketty, Thomas (1995), "Social Mobility and Redistributive Policies", Quarterly Journal of Economics, vol.110, pp. 551-584.

Piketty, Thomas and Emmanuel Saez (2006), "Evolution of Top Incomes: A Historical and International Perspective", American Economic Review, vol.96, no.2, pp. 200-205.

Ravallion, Martin. and Michael. Lokshin (2000), "Who Wants to Redistribute? The tunnel effect in 1990 Russia", Journal of Public Economics, vol.76, pp. 87-104.

Tomioka, Jun and Fumio Ohtake (2005), "On the perception of 'rising economic 
inequality' in Japan”, Osaka Economic Papers (in Japanese), vol.54, no.4, pp.421-436. 
Figure 1: Trend in Economic Inequality in Japan and the U.S.

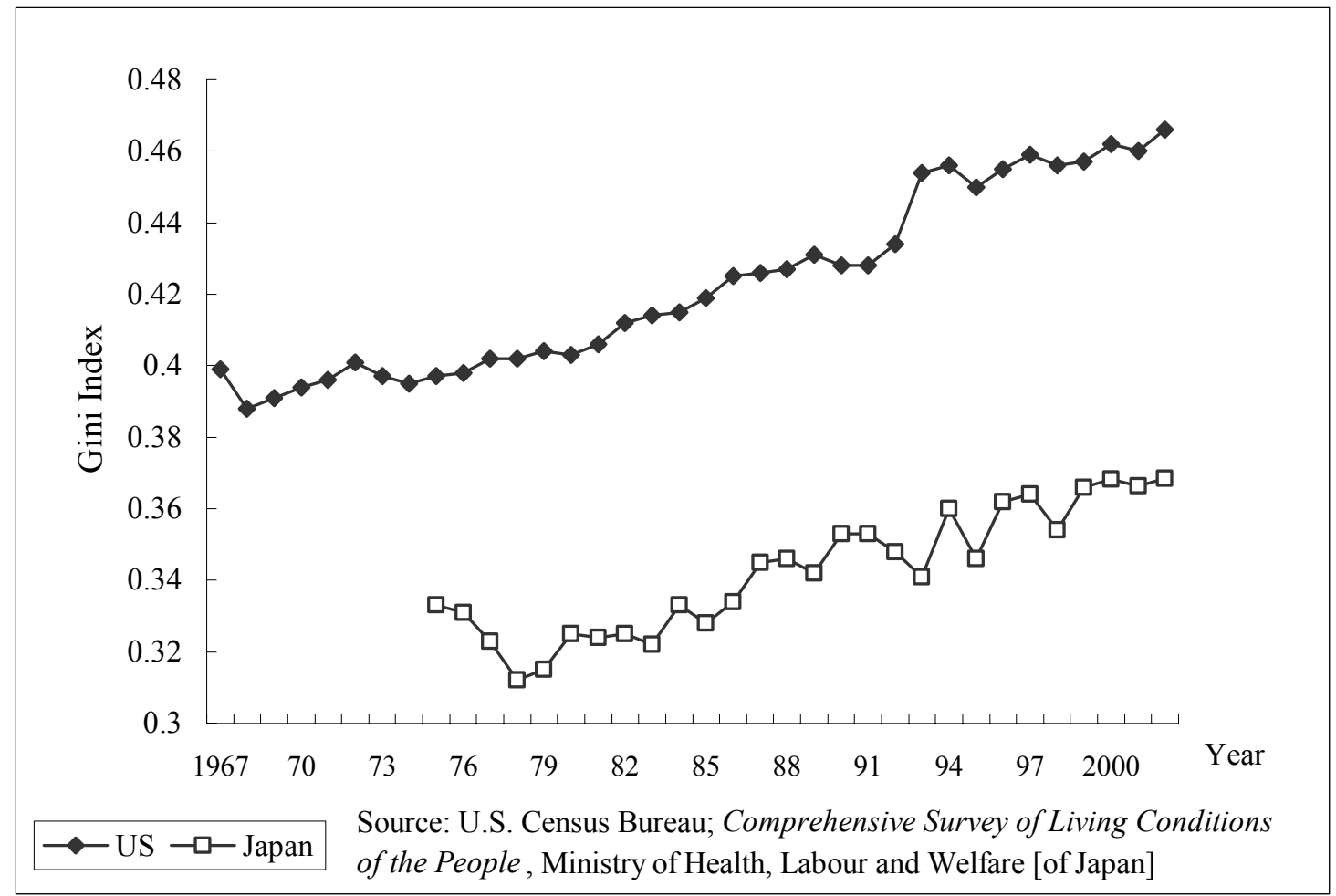

Figure 2: Recognition and Expectation of the Income Gap Expansion (Japan-U.S. comparison)

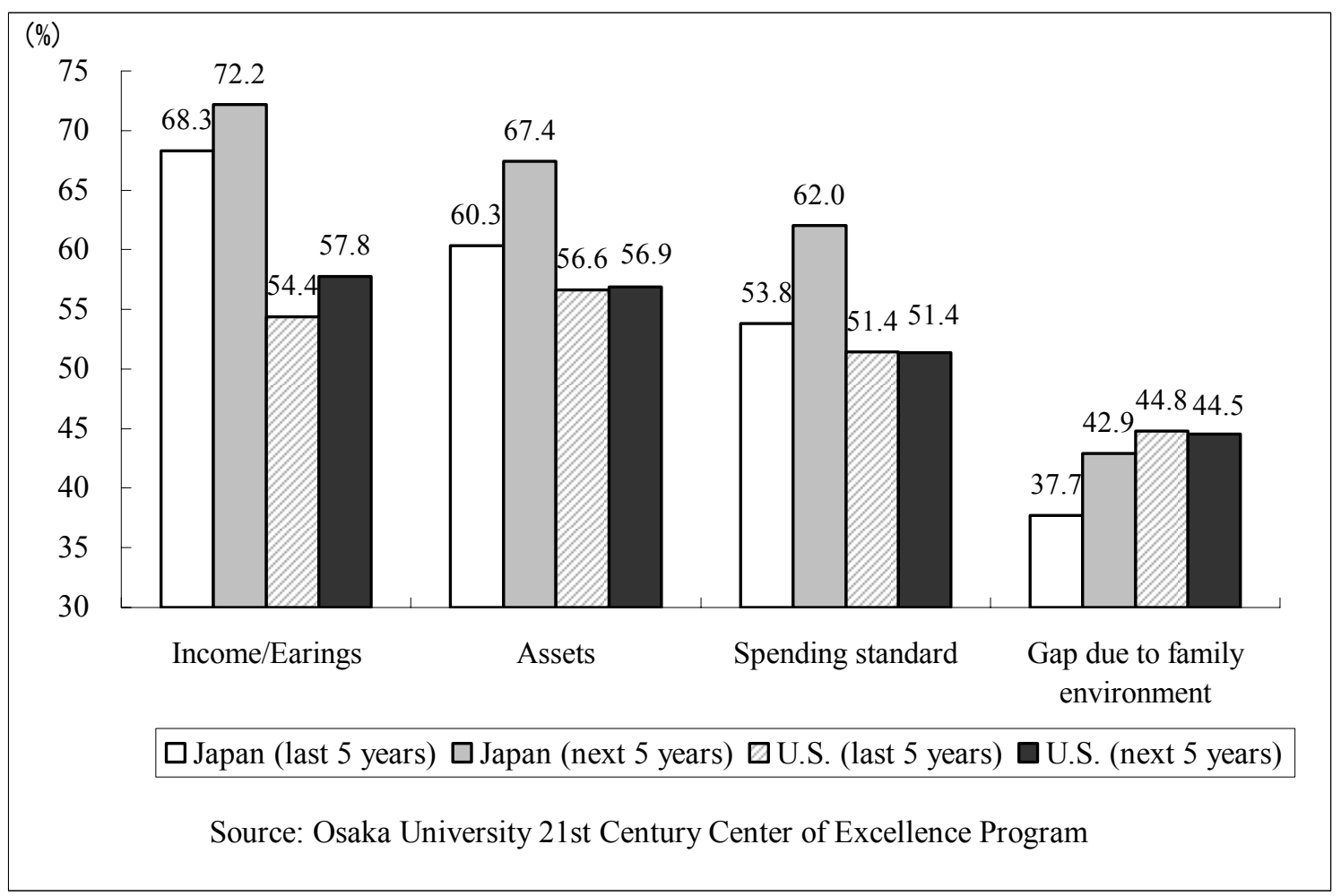


Figure 3: Recognition of and Attitude toward the Income Gap: Japan-U.S. Comparison

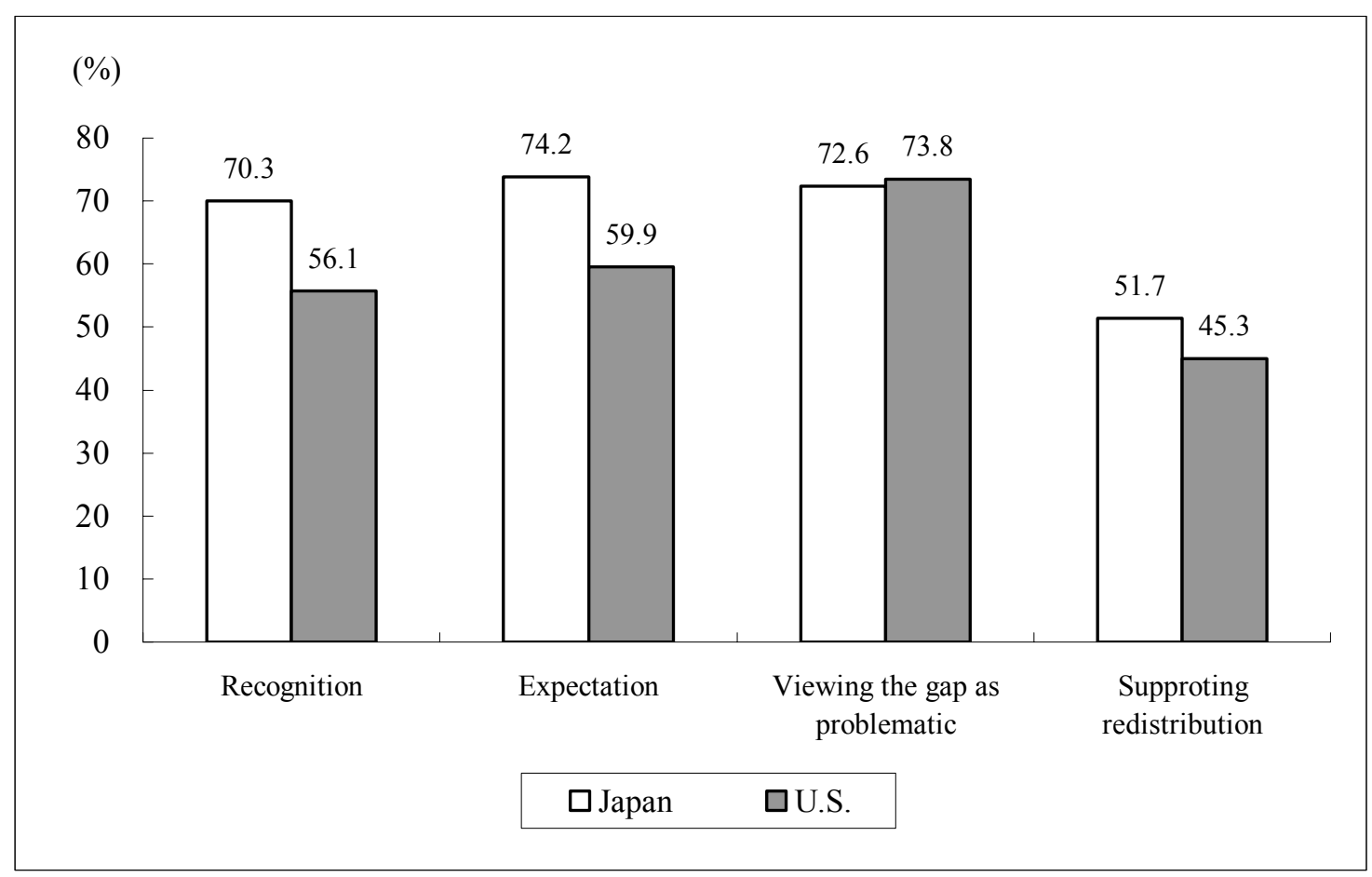

Figure 4: Thoughts on the Income-Gap Expansion by Income Group in Japan

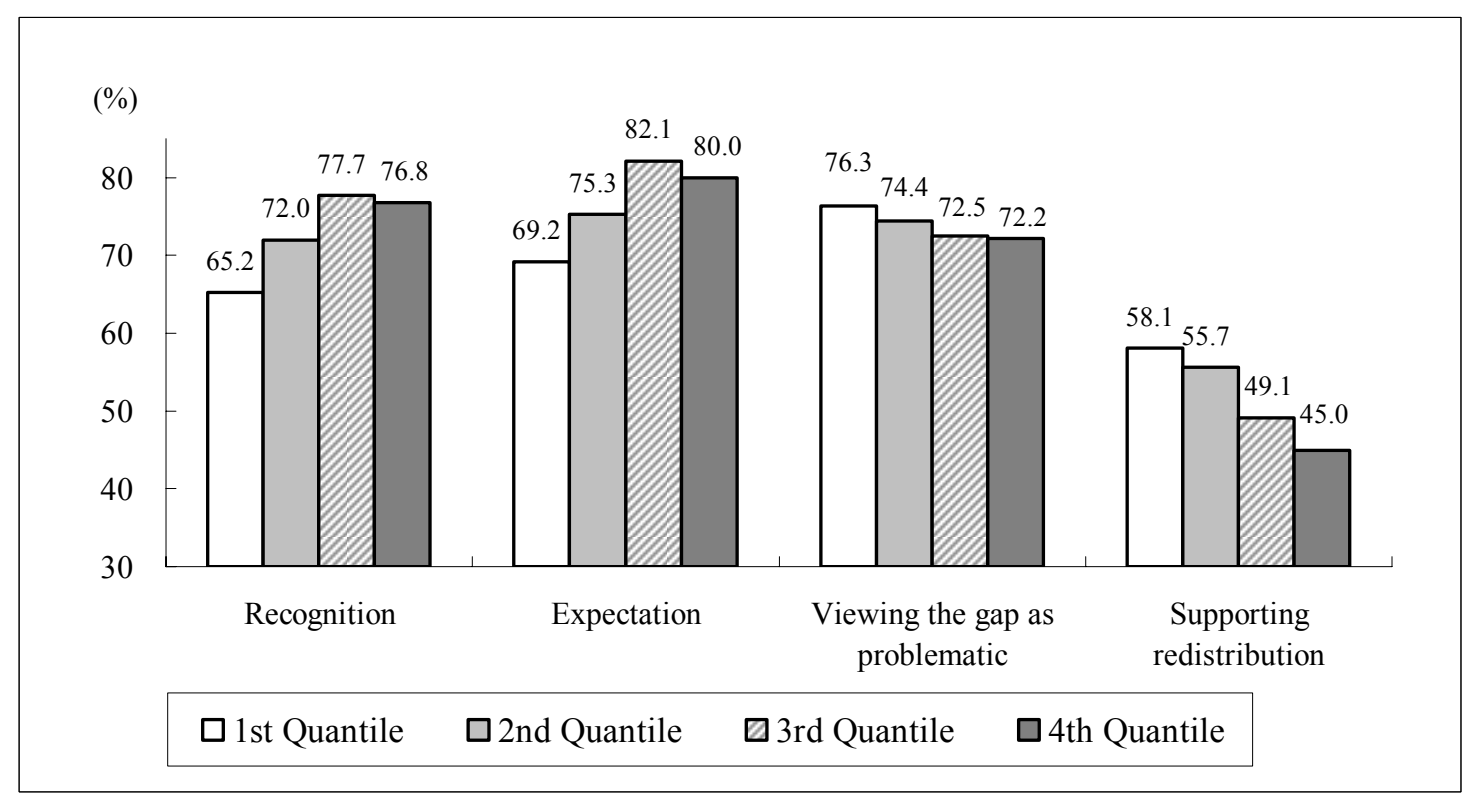


Figure 5: Thoughts on the Income-Gap Expansion by Income Group in the U.S.

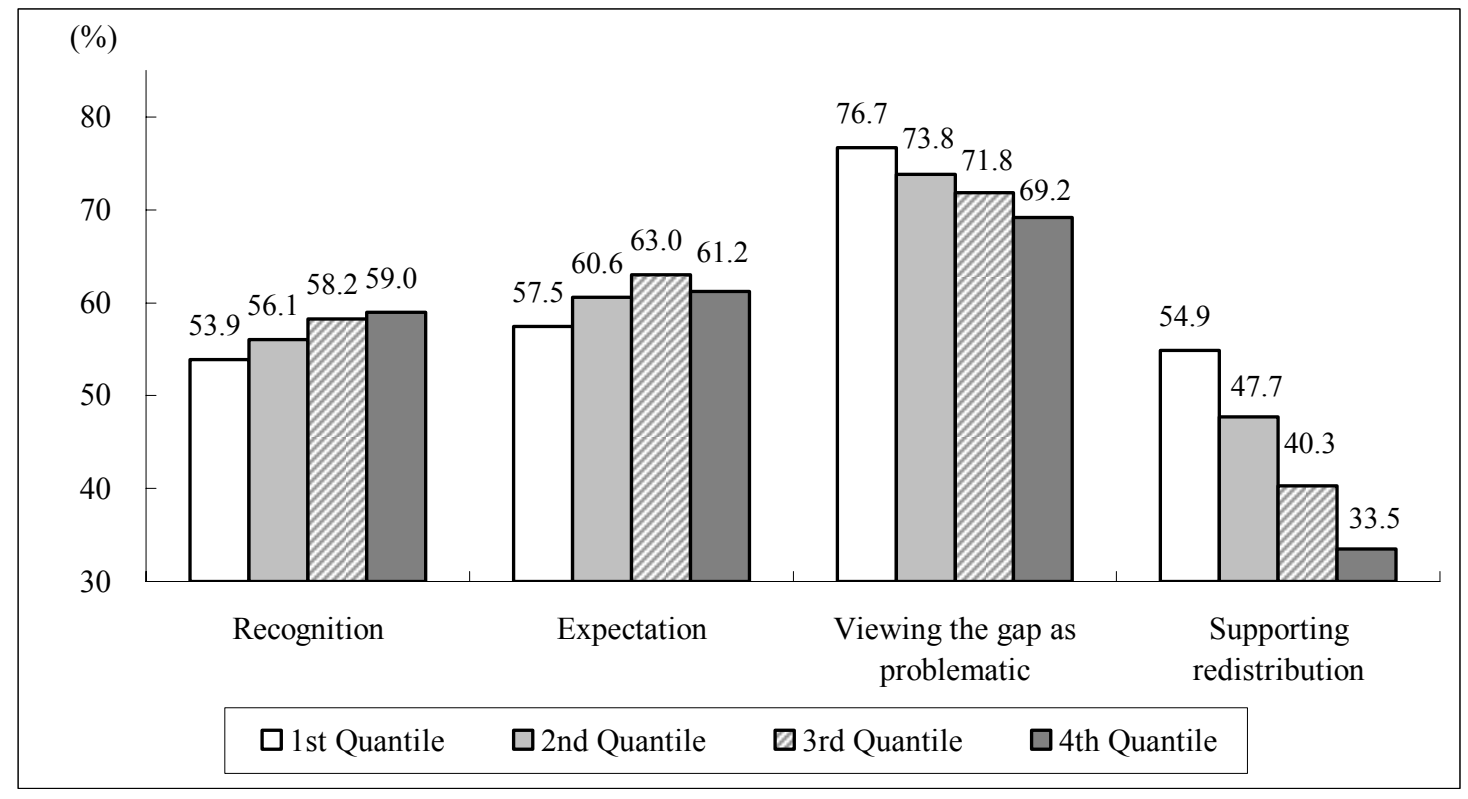

Figure 6: Thoughts on the Income-Gap Expansion by Age Group in Japan

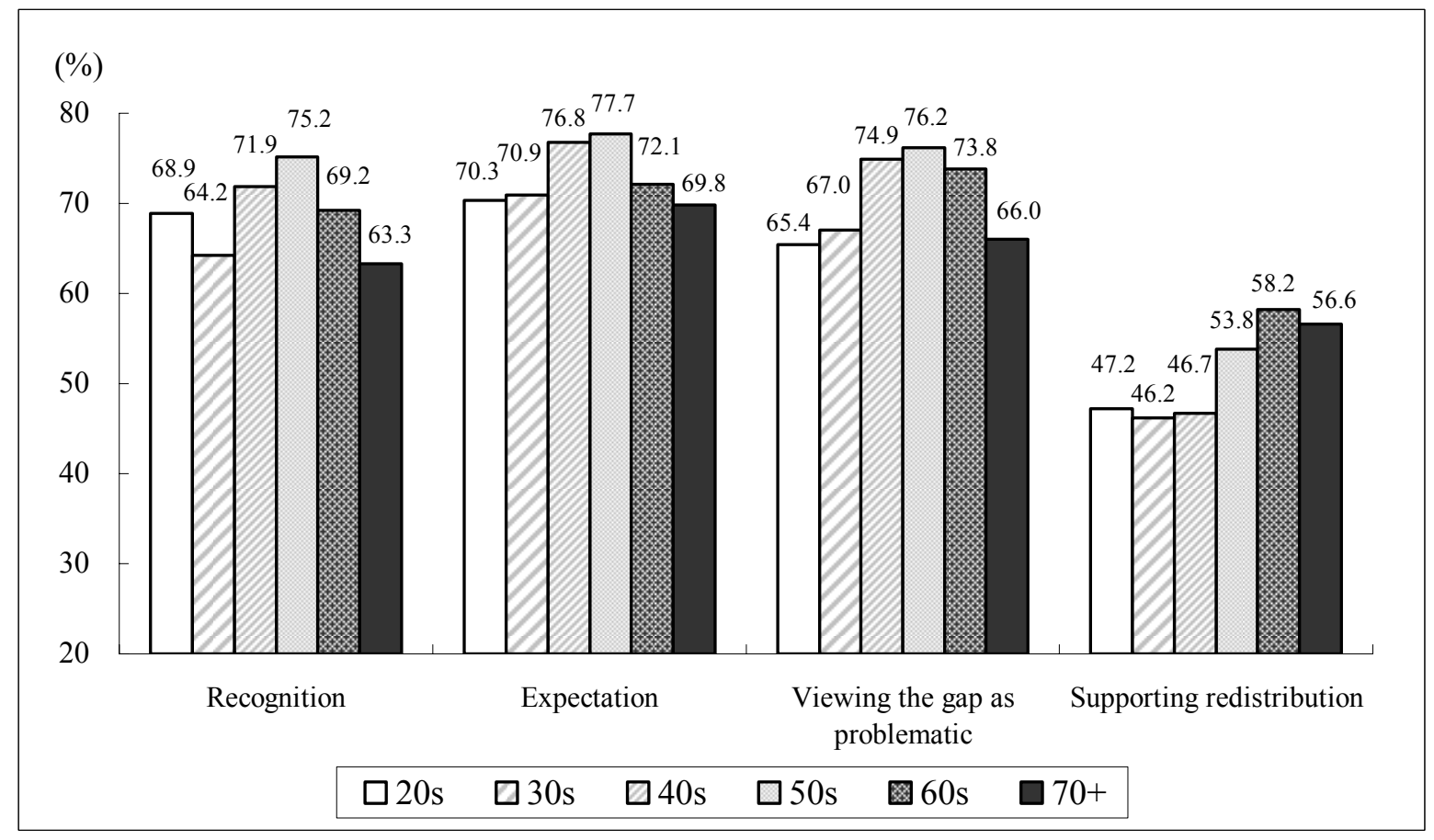


Figure 7: Thoughts on the Income-Gap Expansion by Age Groups in the U.S.

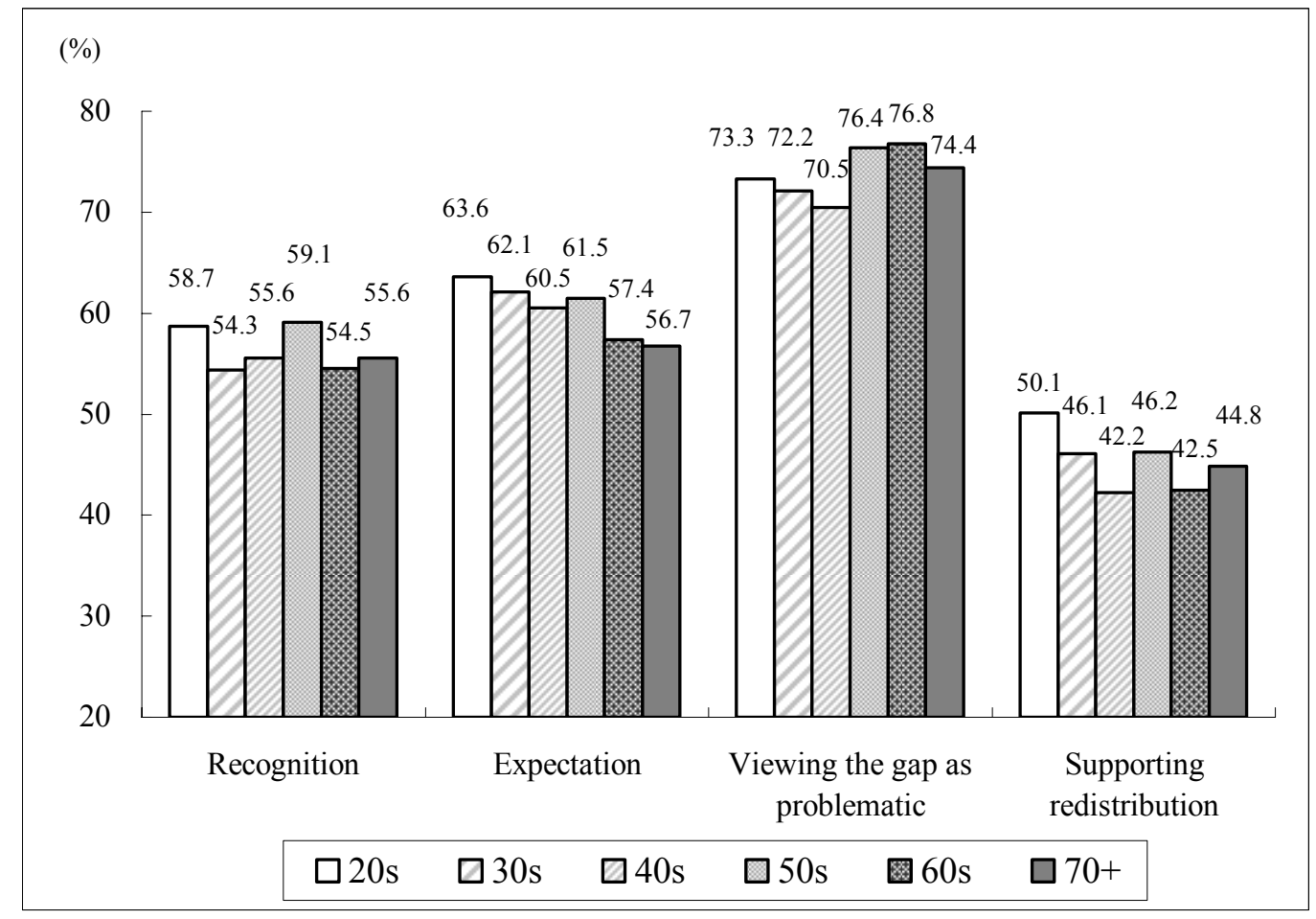

Figure 8: Thoughts on the Widening Income Gap by Gender (Japan)

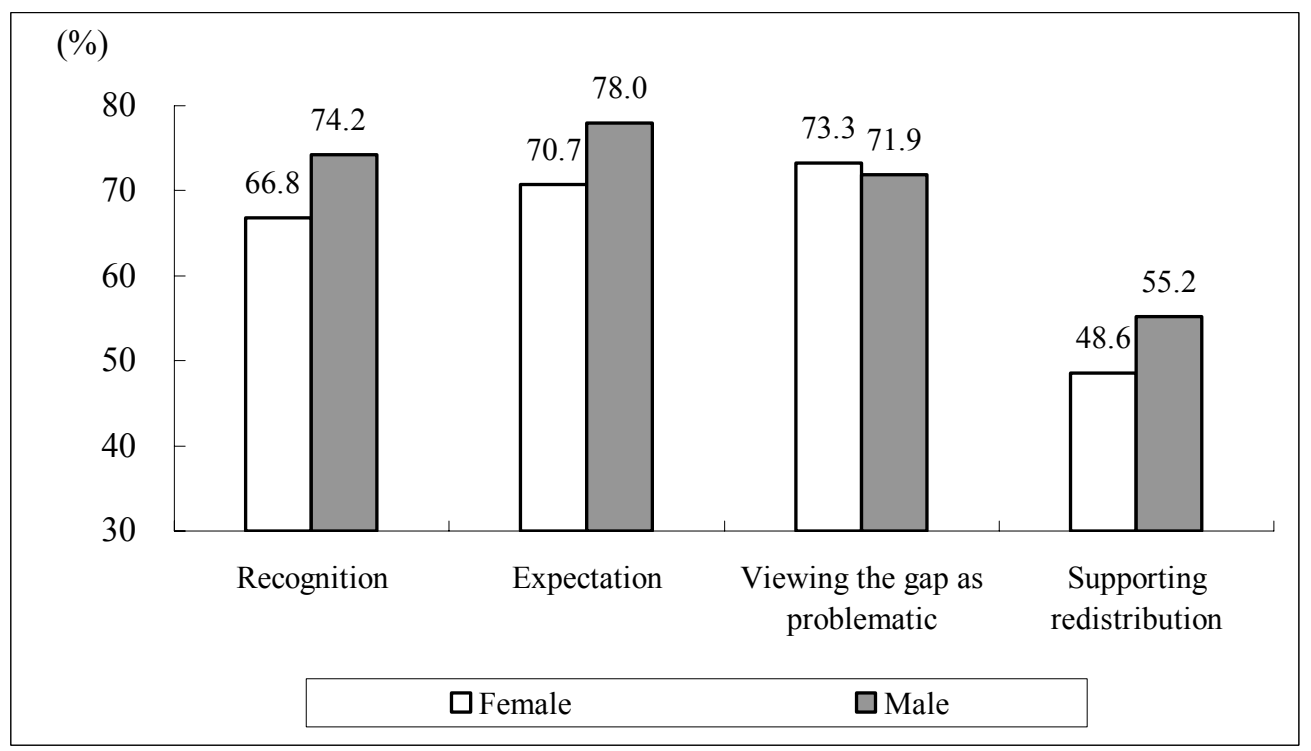


Figure 9: Thoughts on the Widening Income Gap by Gender (U.S.)

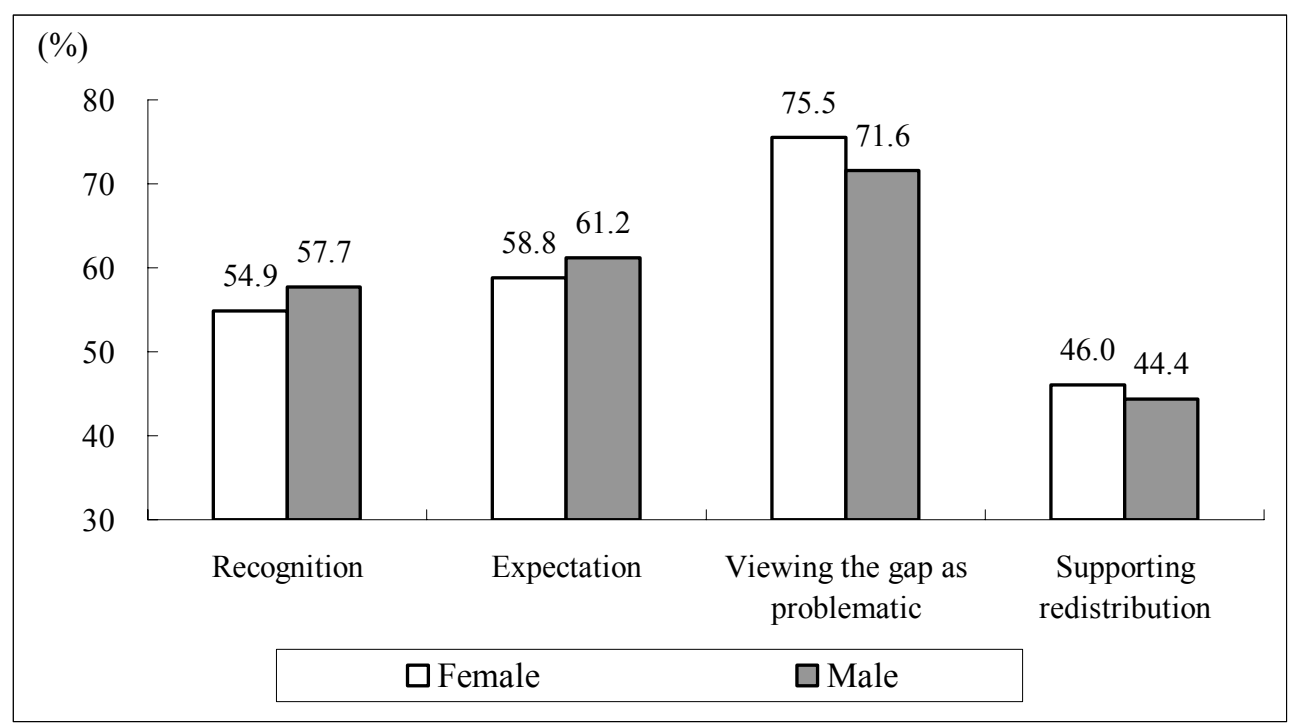

Figure 10: Marginal Effects of Individual Attributes on their Thoughts on Income Gap (Japan)

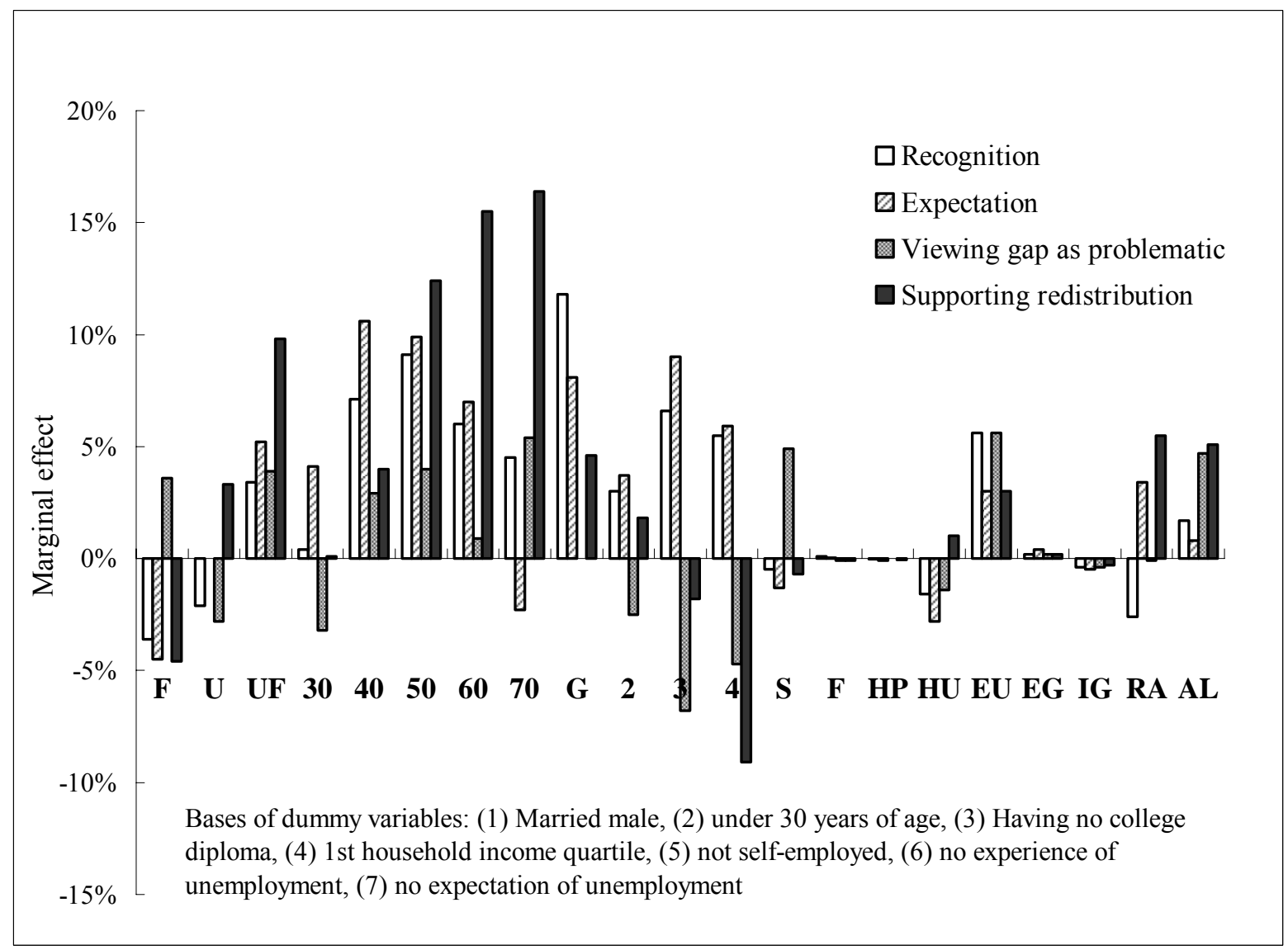


Figure 11: Marginal Effects of Individual Attributes on their Thoughts on Income Gap (U.S.)

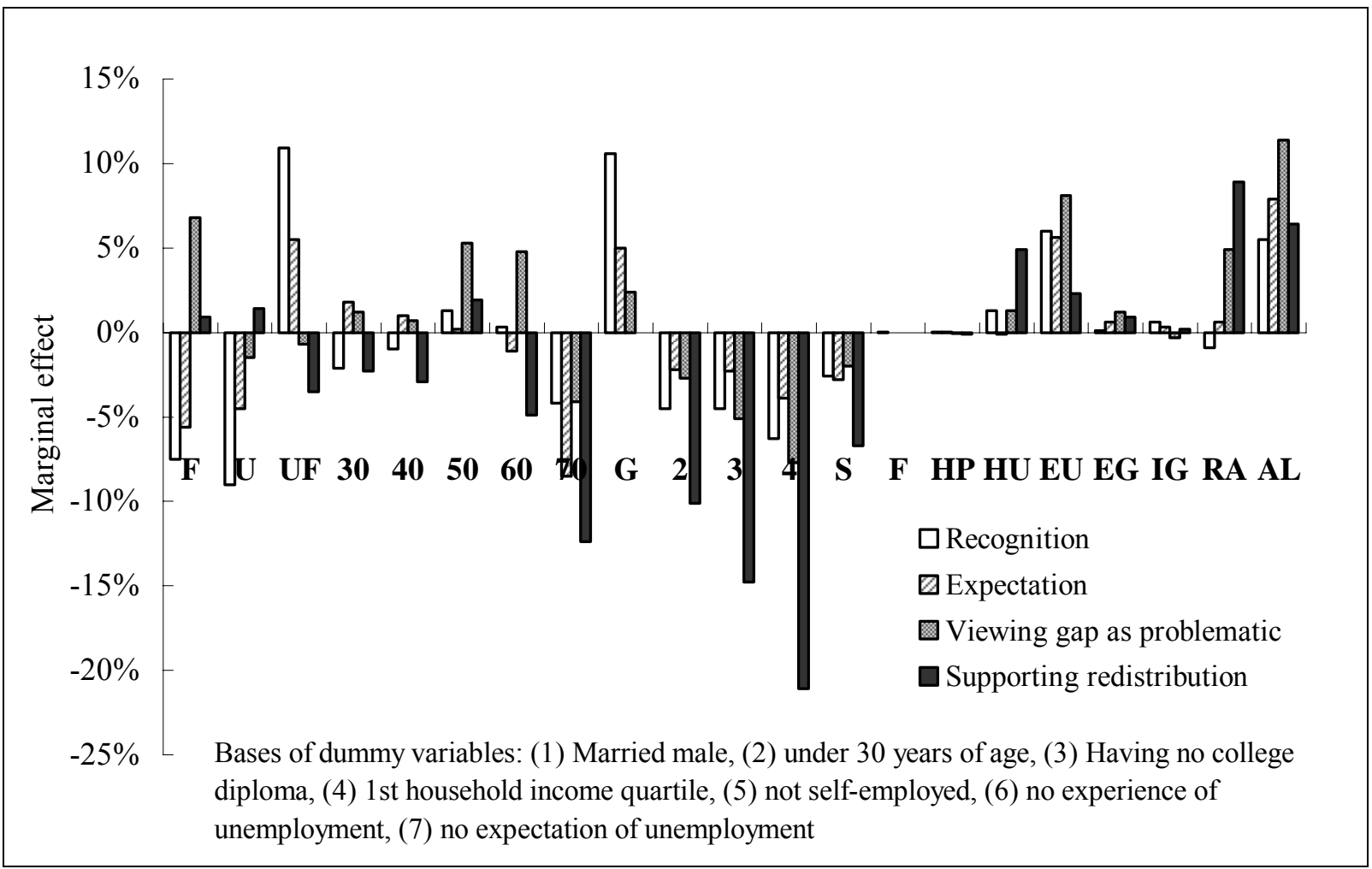

List of Explanatory Variables and their Abbreviations in Figures 10 and 11

\begin{tabular}{llll}
\hline \hline Abbreviation & Variable & Abbreviation & Variable \\
\cline { 1 - 2 } $\mathbf{F}$ & Female & $\mathbf{4}$ & 4th household income quartile \\
$\mathbf{U}$ & Unmarried & $\mathbf{S}$ & Self-employed \\
$\mathbf{U F}$ & Unmarried female & $\mathbf{F}$ & Balance of financial asset (million yen) \\
$\mathbf{3 0}$ & In one's 30s & HP & Value of Housing \& properties (million yen) \\
$\mathbf{4 0}$ & In one's 40s & HU & Have unemployed \\
$\mathbf{5 0}$ & In one's 50s & EU & Expecting unemployment \\
$\mathbf{6 0}$ & In one's 60s & EG & Rate of expenditure growth in 2005 (\%) \\
$\mathbf{7 0}$ & Of 70 years of age and over & IG & Rate of income growth in 2005 (\%) \\
$\mathbf{G}$ & Graduates & RA & Risk aversion (probability of rain) \\
$\mathbf{2}$ & 2nd household income quartile & AL & Altruistic attitude \\
$\mathbf{3}$ & 3rd household income quartile & & \\
\hline
\end{tabular}


Figure 12: What Decides One's Income?

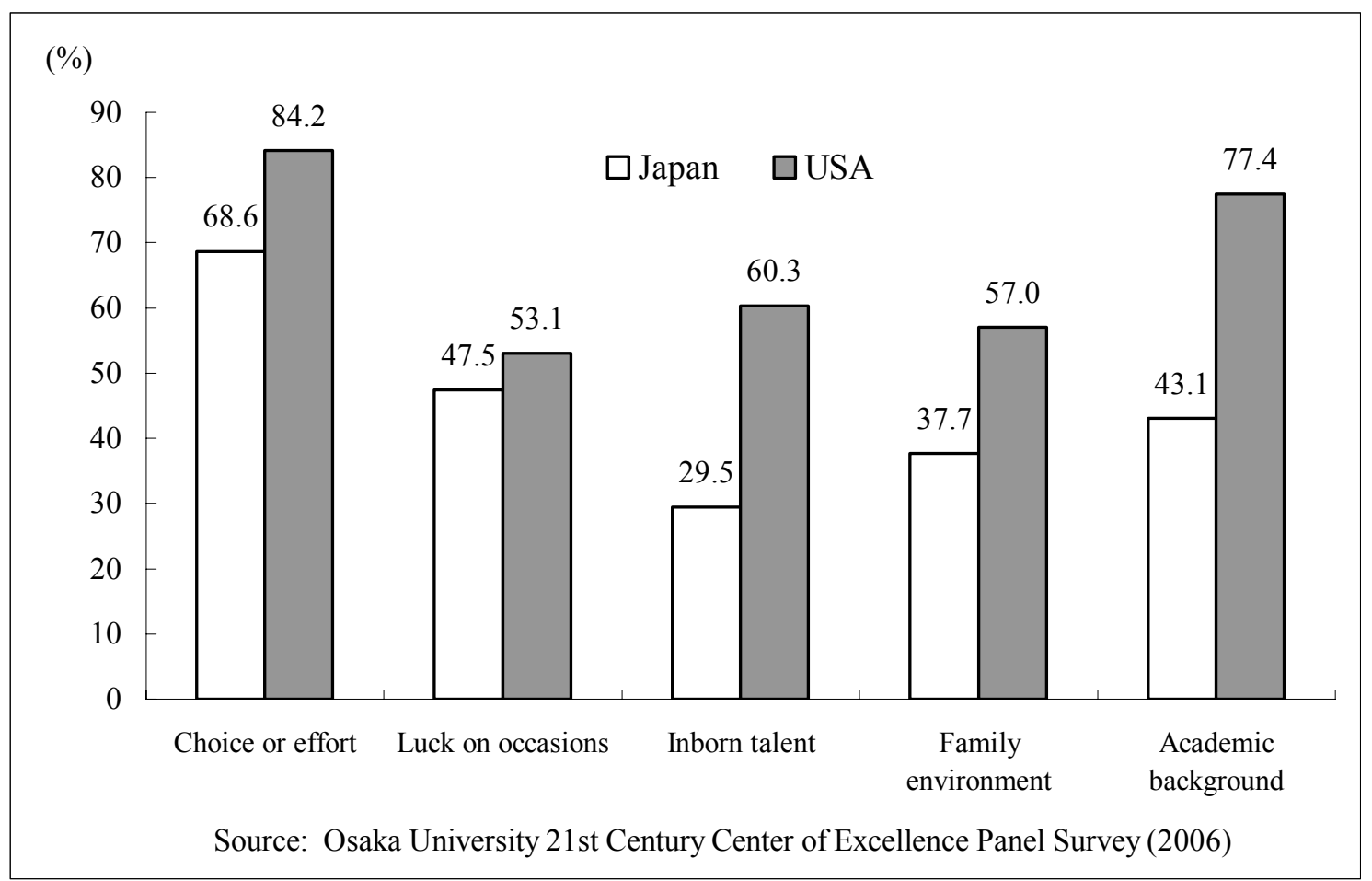

Figure 13: What should Decide One's Income?

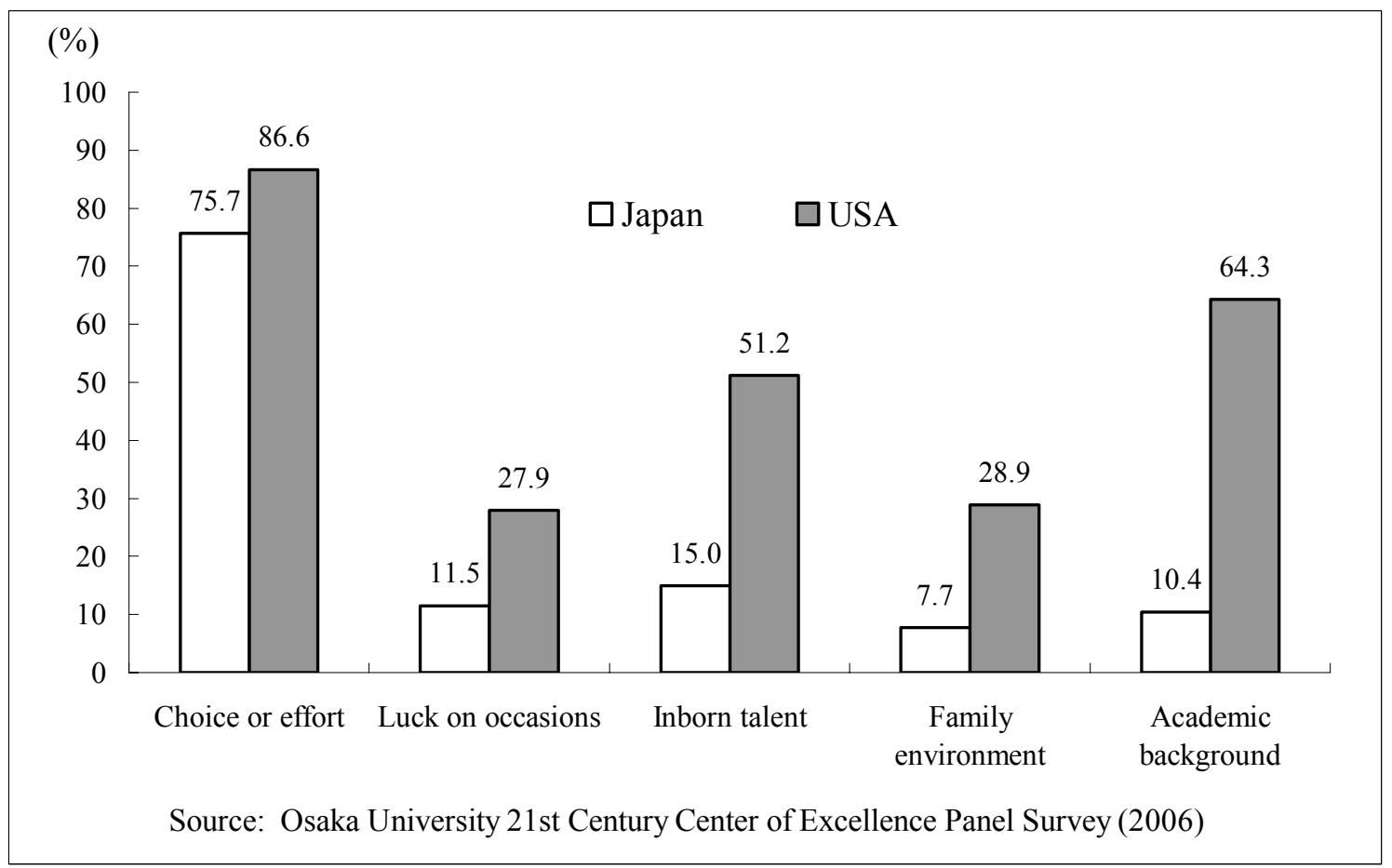


Table 1: Desirable determinants of income: Japan-U.S. comparison by age (\%)

\begin{tabular}{|c|c|c|c|c|c|c|c|c|c|c|}
\hline \multirow[b]{2}{*}{ Age } & \multicolumn{2}{|c|}{ Choice or effort } & \multicolumn{2}{|c|}{$\begin{array}{c}\text { Luck on } \\
\text { occasions }\end{array}$} & \multicolumn{2}{|c|}{ Inborn talent } & \multicolumn{2}{|c|}{$\begin{array}{c}\text { Family } \\
\text { environment }\end{array}$} & \multicolumn{2}{|c|}{$\begin{array}{c}\text { Academic } \\
\text { background }\end{array}$} \\
\hline & Japan & U.S. & Japan & U.S. & Japan & U.S. & Japan & U.S. & Japan & U.S. \\
\hline$<30$ & 79.4 & 87.1 & 17.1 & 26.1 & 23.5 & 50.6 & 7.1 & 28.1 & 12.1 & 65.1 \\
\hline $30 \mathrm{~s}$ & 83.7 & 88.5 & 15.3 & 25.6 & 20.4 & 47.1 & 11.3 & 28.4 & 11.0 & 66.3 \\
\hline $40 \mathrm{~s}$ & 79.3 & 87.7 & 10.2 & 29.9 & 15.7 & 49.0 & 6.8 & 30.9 & 12.0 & 63.6 \\
\hline $50 \mathrm{~s}$ & 75.1 & 89.6 & 9.3 & 26.4 & 12.0 & 54.0 & 6.6 & 26.1 & 8.8 & 63.1 \\
\hline $60 \mathrm{~s}$ & 70.5 & 90.3 & 10.4 & 29.7 & 11.7 & 51.1 & 7.5 & 26.8 & 10.5 & 65.6 \\
\hline$\geq 70$ & 65.9 & 89.6 & 16.5 & 35.0 & 10.6 & 65.8 & 11.8 & 37.9 & 8.2 & 74.8 \\
\hline Average & 76.6 & 88.8 & 11.6 & 28.6 & 15.2 & 52.8 & 7.8 & 29.5 & 10.5 & 66.1 \\
\hline
\end{tabular}

\section{Table 2: Values-Recognition Gap concerning Income Determination and Perception of Income Gap Expansion}

\begin{tabular}{|c|c|c|c|c|c|c|c|c|}
\hline \multirow{3}{*}{$\begin{array}{l}\text { Disagreement between } \\
\text { desirable and recognized } \\
\text { determinants of income }\end{array}$} & \multirow{2}{*}{\multicolumn{2}{|c|}{$\begin{array}{l}\text { Share in the entire } \\
\text { sample of each } \\
\text { country }(\%)\end{array}$}} & \multicolumn{6}{|c|}{$\begin{array}{l}\text { Share among those having a particular disagreement between } \\
\text { their desirable and recognized determinants of income }\end{array}$} \\
\hline & & & \multicolumn{2}{|c|}{$\begin{array}{l}\text { Recognizing the } \\
\text { expansion of } \\
\text { income gap (\%) }\end{array}$} & \multicolumn{2}{|c|}{$\begin{array}{l}\text { Expecting the } \\
\text { expansion of } \\
\text { income gap }(\%)\end{array}$} & \multicolumn{2}{|c|}{$\begin{array}{l}\text { Viewing the gap as } \\
\text { problematic (\%) }\end{array}$} \\
\hline & Japan & U.S. & Japan & U.S. & Japan & U.S. & Japan & U.S. \\
\hline $\begin{array}{l}\text { Income is decided by } \\
\text { inborn talent though it } \\
\text { should not be }\end{array}$ & 23.9 & 19.9 & 73.0 & 59.9 & 75.1 & 61.2 & 72.8 & 74.0 \\
\hline $\begin{array}{l}\text { Income is decided by } \\
\text { academic background } \\
\text { though it should not be }\end{array}$ & 52.3 & 21.2 & 75.1 & 55.2 & 77.3 & 58.1 & 77.1 & 75.5 \\
\hline $\begin{array}{l}\text { Income is decided by } \\
\text { luck on occasions though } \\
\text { it should not be }\end{array}$ & 37.9 & 29.0 & 74.9 & 61.1 & 79.4 & 62.2 & 74.2 & 77.5 \\
\hline $\begin{array}{l}\text { Income is decided by } \\
\text { one's family environment } \\
\text { though it should not be }\end{array}$ & 31.8 & 32.2 & 75.8 & 60.0 & 80.2 & 62.8 & 76.2 & 79.5 \\
\hline $\begin{array}{l}\text { Share in the entire } \\
\text { sample of each country }\end{array}$ & - & - & 70.4 & 56.3 & 74.2 & 59.8 & 72.7 & 73.9 \\
\hline
\end{tabular}


Table 3: Values and Recognition concerning the Income Gap

\begin{tabular}{lcc}
\hline \hline Values & Japan (\%) & U.S. (\%) \\
\hline $\begin{array}{l}\text { The society should have a wide enough income gap. } \\
\begin{array}{l}\text { Equal opportunity of becoming rich should be given by } \\
\text { the society. }\end{array}\end{array}$ & 69.7 & 63.7 \\
$\begin{array}{l}\text { In the society, everyone should be able to gain enough } \\
\text { income for a minimum standard of living }\end{array}$ & 86.0 & 81.8 \\
$\begin{array}{l}\text { Our society should give enough help to people having } \\
\text { difficulties in living }\end{array}$ & 61.9 & 63.6 \\
\hline \hline $\begin{array}{l}\text { Recognition } \\
\text { Willingness to work is decided by whether or not the } \\
\text { society has a wide enough income gap. }\end{array}$ & Japan (\%) & U.S. (\%) \\
$\begin{array}{l}\text { Equal opportunity of becoming rich is given by the } \\
\text { society. }\end{array}$ & 28.8 & 25.5 \\
$\begin{array}{l}\text { There are people who cannot gain enough income for a } \\
\text { minimum standard of living. }\end{array}$ & 57.4 & 63.0 \\
$\begin{array}{l}\text { Our society is giving enough help to people having } \\
\text { difficulties in living. }\end{array}$ & 15.3 & 37.6 \\
\hline
\end{tabular}

Table 4: Proportion of Those Who Think that Equal Opportunity for Becoming Rich is Given by the Society (\%)

\begin{tabular}{lcccccc}
\hline \hline Age & $20 \mathrm{~s}$ & $30 \mathrm{~s}$ & $40 \mathrm{~s}$ & $50 \mathrm{~s}$ & $60 \mathrm{~s}$ & $70 \mathrm{~s}^{+}$ \\
\hline Japan & 9.9 & 13.7 & 11.4 & 16.8 & 20.2 & 23.3 \\
U.S. & 39.7 & 35.9 & 42.9 & 45.4 & 50.8 & 50.7 \\
\hline
\end{tabular}


Appendix 1: Questions in Osaka University 21st Century Center of Excellence Panel Survey

27. Suppose that you found a well-known charity that gave financial help to people who typically had about one-fifth of your family income per person. Up to how much of your own family income per month would you be willing to give the charity if you knew the money would go directly to benefit these people? (X ONE Box)

$1 \square$ Up to $2 \%$ of your family income per month

$2 \square \quad$ Up to $5 \%$ of your family income per month

$3 \square$ Up to $10 \%$ of your family income per month

$4 \quad$ Up to $20 \%$ of your family income per month

$5 \square \quad$ No help at all

28. Suppose that you found a well-known charity that gave financial help to people who typically had about one-fifth of your family income per person. Up to how much of your own family income per month would you be willing to give the charity if you knew the charity would give twice the amount of your donation directly to benefit these people?

\section{(X ONE Box)}

$1 \square$ Up to $2 \%$ of your family income per month

$2 \square \quad$ Up to $5 \%$ of your family income per month

$3 \square$ Up to $10 \%$ of your family income per month

$4 \square$ Up to $20 \%$ of your family income per month

$5 \square \quad$ No help at all 
42. The following statements are ideas on how people's income and standard of living are decided in the US. What is your opinion of these ideas? (X ONE Box For Each Row)

\begin{tabular}{|c|c|c|c|c|}
\hline 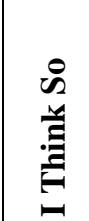 & 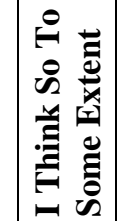 & 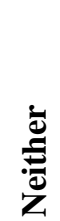 & 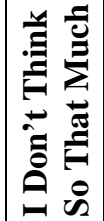 & 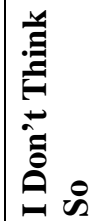 \\
\hline
\end{tabular}

Whether or not one can gain an income or a status that one wishes for is decided by one's choice or effort $1 \square \quad 2 \square \quad 3 \square \quad 4$

Whether or not one can gain an income or a status that one wishes for is decided by one's luck on occasions $1 \square \quad 2 \square \quad 3 \square \quad 4 \square \quad 5$

Whether or not one can gain an income or a status that one wishes for is decided by one's inborn talent $1 \square \quad 2 \square \quad 3 \square \quad 4 \square \quad 5$

Whether or not one can gain an income or a status that one wishes for is decided by one's family environment that one grew up in $1 \square \quad 2 \square \quad 3 \square \quad 4 \square \quad 5$

Whether or not one can gain an income or a status that one wishes for is decided by one's academic background $1 \square$

One's willingness to work is decided by whether or not it is a society where a wide enough income gap exists $1 \square \quad 2 \square \quad 3 \square \quad 4 \square \quad 5 \square$

Even though one is poor at present, equal opportunity of becoming rich is given by the society $1 \square \quad 2 \square \quad 3 \square \quad 4 \square \quad 5 \square$

Even if one works diligently, there are people who cannot gain enough income for a minimum standard of living $1 \square \quad 2 \square \quad 3 \square \quad 4 \square \quad 5$ Our society is giving enough help to people who are so poor and have difficulties in living 1 
43. The following ideas are about how people's income and standard of living should be decided. What is your opinion on these ideas? (X ONE Box For EACH Row)

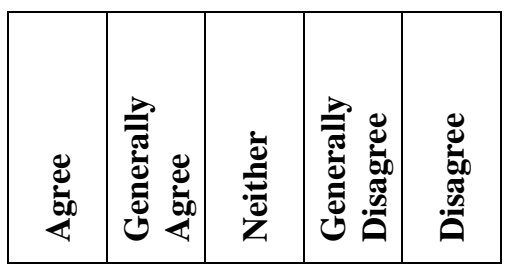

Whether or not one can gain an income or a status that one wishes for should be decided by one's choice or effort $1 \square \quad 2 \square \quad 3 \square \quad 4$ 5

Whether or not one can gain an income or a status that one wishes for should be decided by one's luck on occasions $1 \square \quad 2 \square \quad 3 \square \quad 4 \square \quad 5$

Whether or not one can gain an income or a status that one wishes for should be decided by one's inborn talent $2 \square \quad 3 \square \quad 4 \square \quad 5$

Whether or not one can gain an income or a status that one wishes for should be decided by one's family environment that they grew up in

Whether or not one can gain an income or a status that one wishes for should be decided by one's academic background $1 \square$

One's willingness to work should be decided by whether or not it is a society where a wide enough income gap exists $1 \square \quad 2 \square \quad 3 \square \quad 4$

Even though one is poor at present, equal opportunity of becoming rich should be given by the society $1 \square$

If one works diligently, there should be a society where everyone can gain enough income for a minimum standard of living 1

Our society should give enough help to people who are so poor and have difficulties in living 1 
44. How do you think the following gaps in the US have changed in last 5 years? (X ONE Box For EACH Row)

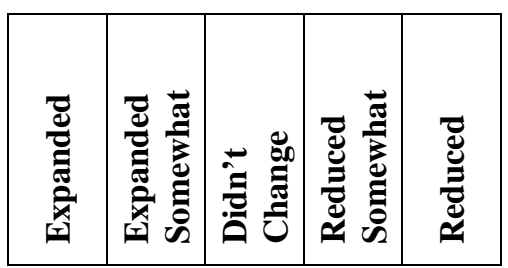

Gap between income or earnings $1 \square \quad 2 \square \quad 3 \square \quad 4 \square \quad 5 \square$

Gap between assets such as savings, stocks, land and housing that one holds $1 \square \quad 2 \square \quad 3 \square \quad 4 \square \quad 5$

Income gap due to difference between families which one grew up in $1 \square \quad 2 \square \quad 3 \square \quad 4 \square \quad 5 \square$

Gap between spending standard $1 \square \quad 2 \square \quad 3 \square \quad 4 \square \quad 5$

45. How do you think the following gaps in the US will change in next 5 years? (X ONE

\section{Box For EACH Row)}

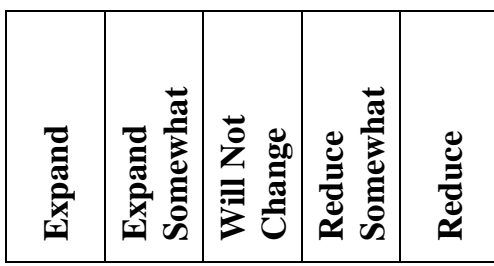

Gap between income or earnings $1 \square \quad 2 \square \quad 3 \square \quad 4 \square \quad 5$

Gap between sums of assets such as savings, stocks, land and housing that one holds $1 \square \quad 2 \square \quad 3 \square \quad 4 \square \quad 5$

Income gap due to difference between families which one grows up in

Gap between spending standard $1 \square \quad 2 \square \quad 3 \square \quad 4 \square \quad 5$ $1 \square \quad 2 \square \quad 3 \square \quad 4 \square \quad 5$ 
46. How much of a problem do you think the current expansion of the income gap is? (X ONE Box)

$1 \square \quad$ It's a big problem

$2 \square \quad$ It's somewhat of a problem

$3 \square \quad$ Neither

$4 \quad$ It's not much of a problem

$5 \square \quad$ It's not a problem at all

$6 \square \quad$ I don't know

47. What is your opinion if the government alters taxation system and social security policy indicated below? (X ONE Box For EACH Row)

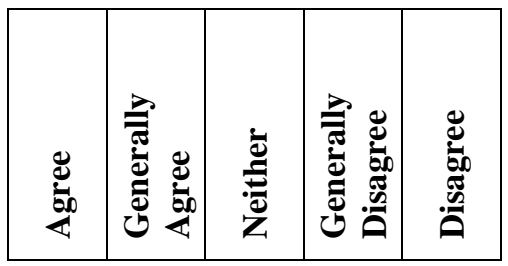

Using taxation system and social security policy, to enforce

redistribution of income from the rich to the poor $1 \square \quad 2 \square \quad 3 \square \quad 4 \square \quad 5$

Increase supply of public housing for people of low income ...... $\square \quad 2 \square \quad 3 \square \quad 4 \square \quad 5 \square$

To maintain the pension system, decrease pension benefit level

To maintain pension benefit level, increase the amount which the pension is covered by insurance $.1 \square \quad 2 \square \quad 3 \square \quad 4 \square \quad 5$

Raise the age which pension payment starts and keep the pension benefit level 1

Decrease the pension benefits paid to people of high income $1 \square \quad 2 \square \quad 3 \square \quad 4 \square \quad 5 \square$

Tighten the standard for providing welfare benefits $1 \square \quad 2 \square \quad 3 \square \quad 4 \square \quad 5$ 


\section{Appendix 2: Estimation of the Constant Relative Risk Aversion (CRRA) Parameter}

Each individual coefficient of constant relative risk aversion was estimated through the following procedure, referring to the method in Kimball et al. (2005).

First, the measurement of risk preference is based on the data collected through a series of questions below.

8. Considering the following two ways of receiving your monthly income, which is preferable to you? Assume that the job assignment is the same under these situations. If you are a dependent (e.g., student, housewife, etc.), answer this question taking your living expense as your monthly income. (X ONE Box)

$1 \square$ Your monthly income has a 50\% chance of doubling, but also has a $50 \%$ chance of decreasing by $30 \% \rightarrow$ (Answer Qu. 8a)

8a. Of the following two jobs, which would you prefer? (X ONE Box)

$1 \square \quad$ A job that has a $50 \%$ chance of the monthly income doubling, but also a $50 \%$ chance of the monthly income being cut in half

$2 \square \quad$ A job with which your monthly income is guaranteed to increase by $5 \%$
$2 \square$ Your monthly income is guaranteed to increase by $5 \% \rightarrow$ (Answer Qu. 8b)

8b. Of the following two jobs, which would you prefer? (X ONE Box)

$1 \square \quad$ A job that has a $50 \%$ chance of the monthly income doubling, but also a $50 \%$ chance of the monthly income decreasing by $10 \%$

$2 \square \quad$ A job with which your monthly income is guaranteed to increase by $5 \%$

From the above the combination of choices between the variable wages and the constant ones, the degree of risk tolerance, defined as the inverse of CRRA coefficient, can be classified into the following four categories:

(1) the variable wages in the question 8 and $8 \mathrm{a}$,

(2) the variable wage in the question 8 while the stable one in $8 \mathrm{a}$,

(3) the constant wage in the question 8 while the variable one in $8 b$,

(4) the constant wages in the question 8 and $8 b$. 
That is, the degree of risk tolerance becomes weaker for categories of larger numbers. The category (1), for instance, shows the highest risk tolerance among the four.

In the next step, the range of risk tolerance for each category will be set, assuming the CRRA utility function. For example, the coefficient of risk aversion parameter to realize the indifference between the two choices in the question $8 \mathrm{~b}$ will be identified as follows. In the question $8 \mathrm{~b}$, the CRRA coefficient, $\gamma$, has to satisfy the following equation when the expected utility is indifferent:

$$
0.5 \frac{2^{1-\gamma}}{1-\gamma}+0.5 \frac{(1-0.1)^{1-\gamma}}{1-\gamma}=\frac{(1+0.05)^{1-\gamma}}{1-\gamma}
$$

The estimate of $\gamma$ equals 5.29, which becomes the lower bound for the respondents in category (4) above. In other words, only the individuals having the CRRA parameter more than or equal to 5.29 should have proceeded from the question 8 to $8 \mathrm{~b}$ and then could have been classified in (4). The upper bound should be, on the one hand, infinite ${ }^{10}$. Applying the same thought to the question 8 and $8 \mathrm{a}$ similarly, the upper and lower bounds of risk tolerance parameter, or the inverse of CRRA coefficient, of each category can be derived as shown in the table below.

Table A1: The Lower and Upper bounds of Risk Tolerance Parameter (with their corresponding values of CRRA coefficients) for the Four Categories

\begin{tabular}{cccccc}
\hline \hline & \multicolumn{2}{c}{ Bounds (Tolerance) } & & \multicolumn{2}{c}{ Bounds (CRRA) } \\
\cline { 2 - 3 } \cline { 5 - 6 } Categories & Lower & Upper & & Lower & Upper \\
\hline$(1)$ & 1.26 & $\infty$ & & 0 & 0.80 \\
$(2)$ & 0.53 & 1.26 & & 0.80 & 1.90 \\
$(3)$ & 0.19 & 0.53 & & 1.90 & 5.29 \\
$(4)$ & 0.00 & 0.19 & & 5.29 & $\infty$ \\
\hline
\end{tabular}

Third, employing the obtained pairs of upper and lower bounds, the expected values of risk tolerance coefficient will be derived through the maximum likelihood estimation. Let $\theta$ denote the parameter of risk tolerance and assume that it follows the log-normal distribution, or

\footnotetext{
${ }^{10}$ A finite upper bound of the CRRA parameter could not be derived because none of the questions presented a wage schedule being variable and still safer than the one in the question $8 \mathrm{~b}$.
} 


$$
x \equiv \ln \theta \sim \mathrm{N}(\mu, \sigma),
$$

where $\mu$ and $\sigma$ denote the mean and standard deviation of the normal distribution respectively. Besides, suppose $\bar{\theta}_{j}$ and $\underline{\theta}_{j}$ signify its lower and upper bounds for the category $j(=1,2,3$, 4) respectively. Those bounds then take the estimates in Table A1. The probability for $\theta$ of individual $i, x_{i} \equiv \ln \theta_{i}$, to be in $j$ th class can be expressed as:

$$
P(c=j)=P\left(\ln \underline{\theta}_{j}<x_{i}<\ln \bar{\theta}_{j}\right)=\Phi\left(\frac{\ln \bar{\theta}_{j}-\mu}{\sigma}\right)-\Phi\left(\frac{\ln \underline{\theta}_{j}-\mu}{\sigma}\right),
$$

The mark $\Phi$, in addition, denotes the cumulative distribution function of the normal distribution. The logarithm of the above probability can constitute a log-likelihood function defined as:

$$
L(\mu, \sigma \mid \mathrm{c})=\sum_{i \in I} \sum_{j \in J} 1\left[c_{i}=j\right] \ln P(c=j)
$$

Let $1\left[c_{i}=j\right]$ signifies the variable to take one for the inclusion of individual $i$ in class $j$; otherwise, it equals zero. In addition, suppose that letter $I$ and $J$ indicate the total number of respondents and classes respectively. Employing the parameter $\mu$ and $\sigma$ through the maximum likelihood estimation with the log-likelihood function, each expected value of $\theta$ in $j$ can be obtained by the following equation (Kimball et al., 2005).

$$
\begin{aligned}
& E\left(\theta_{i} \mid \ln \underline{\theta}_{j}<x_{i}<\ln \bar{\theta}_{j}\right) \\
& =\exp \left(\mu+\frac{\sigma^{2}}{2}\right) \frac{\int_{\ln \underline{\theta}_{j}}^{\ln \bar{\theta}_{j}} \frac{1}{\sqrt{2 \pi} \sigma} \exp \left(\frac{-\left(y-\mu-\sigma^{2}\right)^{2}}{2 \sigma^{2}}\right) d y}{\int_{\ln \underline{\theta}_{j}}^{\ln \bar{\theta}_{j}} \frac{1}{\sqrt{2 \pi} \sigma} \exp \left(\frac{-(y-\mu)^{2}}{2 \sigma^{2}}\right) d y}
\end{aligned}
$$

Table A2: The Estimates of Risk Tolerance Parameter (with their corresponding CRRA values) for the Four Categories

\begin{tabular}{cccccccc}
\hline \hline & \multicolumn{3}{c}{ Japan } & & \multicolumn{3}{c}{ United States } \\
\cline { 2 - 3 } \cline { 7 - 8 } Categories & \# of obs. & Tolerance & CRRA & & \# of obs. & Tolerance & CRRA \\
\hline$(1)$ & 144 & 2.85 & 0.35 & & 72 & 2.68 & 0.37 \\
$(2)$ & 334 & 0.80 & 1.26 & & 157 & 0.79 & 1.26 \\
$(3)$ & 632 & 0.32 & 3.15 & & 371 & 0.32 & 3.16 \\
$(4)$ & 2,005 & 0.07 & 14.65 & & 1179 & 0.07 & 14.65 \\
\hline
\end{tabular}


Appendix 3: Descriptive Statistics

\begin{tabular}{|c|c|c|c|c|c|c|c|c|}
\hline & & Japan & & & U.S. & & $\begin{array}{r}\text { Japan- } \\
\text { me }\end{array}$ & \\
\hline & $\begin{array}{l}\text { Sample } \\
\text { size }\end{array}$ & Mean & $\begin{array}{l}\text { Std. } \\
\text { dev. }\end{array}$ & $\begin{array}{l}\text { Sample } \\
\text { size }\end{array}$ & Mean & $\begin{array}{l}\text { Std. } \\
\text { dev. }\end{array}$ & (JPN-L & \\
\hline Recognition of gap & 3653 & 0.703 & 0.457 & 3025 & 0.561 & 0.496 & 0.143 & ${ }^{* * *}$ \\
\hline Expectation of gap & 3660 & 0.742 & 0.438 & 3010 & 0.599 & 0.490 & 0.143 & ${ }^{* * *}$ \\
\hline Support for redistribution & 3652 & 0.517 & 0.500 & 3017 & 0.453 & 0.498 & 0.064 & ** \\
\hline Viewing gap as problematic & 3537 & 0.726 & 0.446 & 2973 & 0.738 & 0.440 & -0.012 & \\
\hline
\end{tabular}

Ideas on how people' s income and standard of living are decided

\begin{tabular}{|c|c|c|c|c|c|c|c|c|}
\hline Choice/Effort & 3737 & 0.691 & 0.462 & 3062 & 0.858 & 0.350 & -0.166 & $* * *$ \\
\hline Luck on occasions & 3736 & 0.478 & 0.500 & 3059 & 0.541 & 0.498 & -0.063 & $* *$ \\
\hline Inborn talent & 3728 & 0.297 & 0.457 & 3050 & 0.617 & 0.486 & -0.320 & $* *$ \\
\hline Family environment & 3728 & 0.381 & 0.486 & 3038 & 0.586 & 0.493 & -0.205 & ** \\
\hline Academic background & 3727 & 0.435 & 0.496 & 3051 & 0.792 & 0.406 & -0.357 & *** \\
\hline Income gap & 3712 & 0.292 & 0.455 & 3040 & 0.262 & 0.440 & 0.030 & *** \\
\hline Equal opportunity & 3732 & 0.154 & 0.361 & 3045 & 0.440 & 0.496 & -0.286 & *** \\
\hline Minimum income & 3733 & 0.579 & 0.494 & 3056 & 0.683 & 0.466 & -0.104 & ** \\
\hline Enough help & 3731 & 0.130 & 0.336 & 3062 & 0.383 & 0.486 & -0.253 & 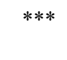 \\
\hline \multicolumn{9}{|c|}{ Ideas on how people' s income and standard of living should be decided } \\
\hline Choice/Effort & 3721 & 0.766 & 0.424 & 3051 & 0.885 & 0.319 & -0.120 & *** \\
\hline Luck on occasions & 3727 & 0.116 & 0.320 & 3044 & 0.286 & 0.452 & -0.170 & *** \\
\hline Inborn talent & 3712 & 0.152 & 0.359 & 3046 & 0.524 & 0.500 & -0.372 & *** \\
\hline Family environment & 3725 & 0.078 & 0.268 & 3043 & 0.296 & 0.457 & -0.219 & *** \\
\hline Academic background & 3722 & 0.105 & 0.307 & 3038 & 0.660 & 0.474 & -0.555 & *** \\
\hline Income gap & 3706 & 0.200 & 0.400 & 3025 & 0.213 & 0.409 & -0.013 & \\
\hline Equal opportunity & 3714 & 0.706 & 0.456 & 3037 & 0.655 & 0.476 & 0.052 & ** \\
\hline Minimum income & 3726 & 0.869 & 0.338 & 3051 & 0.836 & 0.370 & 0.033 & ${ }^{* * *}$ \\
\hline Enough help & 3718 & 0.627 & 0.484 & 3045 & 0.652 & 0.476 & -0.025 & ** \\
\hline Female & 3763 & 0.529 & 0.499 & 3093 & 0.563 & 0.496 & -0.035 & $* * *$ \\
\hline Unmarried & 3752 & 0.137 & 0.344 & 3081 & 0.601 & 0.490 & -0.464 & *** \\
\hline Unmarried Female & 3752 & 0.065 & 0.246 & 3055 & 0.333 & 0.471 & -0.268 & ${ }^{* * *}$ \\
\hline Not employed male & 3763 & 0.067 & 0.250 & 3120 & 0.124 & 0.330 & -0.057 & *** \\
\hline Employed female & 3763 & 0.333 & 0.471 & 3120 & 0.314 & 0.464 & 0.019 & \\
\hline Not employed female & 3763 & 0.183 & 0.386 & 3120 & 0.189 & 0.391 & -0.006 & \\
\hline
\end{tabular}


(Continued)

Age groups

\begin{tabular}{|c|c|c|c|c|c|c|c|c|}
\hline $30 \mathrm{~s}$ & 3763 & 0.166 & 0.372 & 2986 & 0.161 & 0.368 & 0.004 & \\
\hline $40 \mathrm{~s}$ & 3763 & 0.216 & 0.411 & 2986 & 0.199 & 0.400 & 0.016 & \\
\hline $50 \mathrm{~s}$ & 3763 & 0.271 & 0.444 & 2986 & 0.213 & 0.409 & 0.058 & $* * *$ \\
\hline $60 \mathrm{~s}$ & 3763 & 0.234 & 0.424 & 2986 & 0.139 & 0.346 & 0.095 & $* * *$ \\
\hline $70+$ & 3763 & 0.024 & 0.152 & 2986 & 0.149 & 0.356 & -0.125 & $* * *$ \\
\hline Graduates & 3632 & 0.211 & 0.408 & 3092 & 0.353 & 0.478 & -0.143 & $* * *$ \\
\hline \multicolumn{9}{|l|}{ Household income quartile } \\
\hline 2nd quartile & 3102 & 0.390 & 0.488 & 2870 & 0.176 & 0.381 & 0.214 & $* * *$ \\
\hline 3rd quartile & 3102 & 0.131 & 0.337 & 2870 & 0.239 & 0.427 & -0.108 & $* * *$ \\
\hline 4th quartile & 3102 & 0.184 & 0.388 & 2870 & 0.179 & 0.384 & 0.005 & \\
\hline Self-employed & 3686 & 0.095 & 0.294 & 2741 & 0.063 & 0.243 & 0.033 & *** \\
\hline $\begin{array}{l}\text { Financial assets } \\
\text { (in million yen) }\end{array}$ & 2830 & 14.444 & 25.850 & 2767 & 28.976 & 66.023 & -14.531 & $* * *$ \\
\hline $\begin{array}{l}\text { Housing and properties } \\
\text { (in million yen) }\end{array}$ & 3131 & 22.887 & 32.124 & 2942 & 25.783 & 36.574 & -2.896 & $* * *$ \\
\hline Experience of unemployment & 3700 & 0.187 & 0.390 & 3034 & 0.228 & 0.420 & -0.041 & $* * *$ \\
\hline Expecting unemployment & 3627 & 0.271 & 0.444 & 3025 & 0.292 & 0.455 & -0.021 & * \\
\hline $\begin{array}{l}\text { Rate of consumption growth } \\
(\%)\end{array}$ & 3386 & 1.414 & 4.288 & 2878 & 3.003 & 3.919 & -1.588 & *** \\
\hline Rate of income growth (\%) & 3380 & -0.619 & 3.971 & 2880 & 1.625 & 3.726 & -2.245 & *** \\
\hline $\begin{array}{l}\text { Risk-aversion index } \\
1 \text { - chance of rain }(\%) / 100\end{array}$ & 3690 & 0.501 & 0.202 & 2936 & 0.348 & 0.298 & 0.152 & $* * *$ \\
\hline CRRA coefficient & 3115 & 10.217 & 5.992 & 1779 & 10.496 & 5.861 & -0.278 & \\
\hline Altruism & 3633 & 0.614 & 0.487 & 3047 & 0.781 & 0.414 & 0.168 & $* * *$ \\
\hline
\end{tabular}

Note: $*$ significant at $10 \% ; * *$ significant at $5 \% ; * * *$ significant at $1 \%$ 


\section{Appendix 4: Estimation of the Probit Models to Explain the Recognition and Value Judgments concerning the Gap and the Support for Redistributive Policies}

\section{A. Empirical results for Japan (marginal effects (\%))}

\begin{tabular}{|c|c|c|c|c|}
\hline Dependent variables & $\begin{array}{l}\text { Recognizing } \\
\text { the gap }\end{array}$ & $\begin{array}{l}\text { Expecting } \\
\text { the gap }\end{array}$ & $\begin{array}{l}\text { Viewing the } \\
\text { gap as } \\
\text { problematic }\end{array}$ & $\begin{array}{l}\text { Supporting } \\
\text { redistribution }\end{array}$ \\
\hline & (1) & (2) & (3) & (4) \\
\hline Female & $-0.036^{*}$ & $-0.045^{* *}$ & $0.036^{*}$ & $-0.046^{*}$ \\
\hline Unmarried & -0.021 & 0.000 & -0.028 & 0.033 \\
\hline Unmarried female & 0.034 & 0.052 & 0.039 & 0.098 \\
\hline \multicolumn{5}{|l|}{ Age groups } \\
\hline $30 \mathrm{~s}$ & 0.004 & 0.041 & -0.032 & 0.001 \\
\hline $40 \mathrm{~s}$ & $0.071^{*}$ & $0.106 * * *$ & 0.029 & 0.040 \\
\hline $50 \mathrm{~s}$ & $0.091 * *$ & $0.099 * * *$ & 0.040 & $0.124 * *$ \\
\hline $60 s$ & 0.060 & $0.070^{*}$ & 0.009 & $0.155^{* * *}$ \\
\hline $70+$ & 0.045 & -0.023 & 0.054 & $0.164 * *$ \\
\hline Graduates & $0.118 * * *$ & $0.081 * * *$ & -0.000 & $0.046^{*}$ \\
\hline \multicolumn{5}{|l|}{ Household income quartile } \\
\hline 2nd quartile & 0.030 & $0.037 *$ & -0.025 & 0.018 \\
\hline 3rd quartile & $0.066^{* *}$ & $0.090 * * *$ & $-0.068 *$ & -0.018 \\
\hline 4th quartile & $0.055^{*}$ & $0.059 * *$ & -0.047 & $-0.091 * *$ \\
\hline Self-employed & -0.005 & -0.013 & $0.049 *$ & -0.007 \\
\hline Financial assets & $0.001^{*}$ & 0.0003 & $-0.001 * * *$ & -0.001 \\
\hline Housing and properties & -0.0002 & $-0.001 *$ & -0.0001 & -0.0005 \\
\hline Experience of unemployment & -0.016 & -0.028 & -0.014 & 0.010 \\
\hline Expectation of unemployment & $0.056^{* * *}$ & 0.030 & $0.056^{* * *}$ & 0.030 \\
\hline Rate of consumption growth $(\%)$ & 0.002 & $0.004^{*}$ & 0.002 & 0.002 \\
\hline Rate of income growth (\%) & -0.004 & $-0.005 * *$ & -0.004 & -0.003 \\
\hline $\begin{array}{l}\text { Risk-aversion index: } \\
\text { 1- chance of rain }(\%) / 100\end{array}$ & -0.026 & 0.034 & -0.001 & 0.055 \\
\hline Altruistic (willing to donate) & 0.017 & 0.008 & $0.047 * *$ & $0.051 * *$ \\
\hline Observations & 2284 & 2280 & 2214 & 2280 \\
\hline Psudo R2 & 0.03 & 0.03 & 0.02 & 0.02 \\
\hline Log likelihood & -1279.52 & -1181.95 & -1235.26 & -1536.81 \\
\hline
\end{tabular}

Note: $*$ significant at $10 \% ; * *$ significant at $5 \% ; * * *$ significant at $1 \%$ 


\section{B. Empirical results for the U.S. (marginal effects (\%))}

\begin{tabular}{|c|c|c|c|c|}
\hline Dependent variables & $\begin{array}{l}\text { Recognizing } \\
\text { the gap }\end{array}$ & $\begin{array}{l}\text { Expecting } \\
\text { the gap }\end{array}$ & $\begin{array}{l}\text { Viewing the } \\
\text { gap as } \\
\text { problematic }\end{array}$ & $\begin{array}{l}\text { Supporting } \\
\text { redistribution }\end{array}$ \\
\hline & (1) & (2) & (3) & (4) \\
\hline Female & $-0.075 * *$ & -0.056 & $0.068 * *$ & 0.009 \\
\hline Unmarried & $-0.090 * *$ & -0.045 & -0.015 & 0.014 \\
\hline Unmarried female & $0.109^{* *}$ & 0.055 & -0.007 & -0.035 \\
\hline \multicolumn{5}{|l|}{ Age groups } \\
\hline $30 \mathrm{~s}$ & -0.021 & 0.018 & 0.012 & -0.023 \\
\hline $40 \mathrm{~s}$ & -0.010 & 0.010 & 0.007 & -0.029 \\
\hline $50 \mathrm{~s}$ & 0.013 & 0.002 & 0.053 & 0.019 \\
\hline $60 \mathrm{~s}$ & 0.003 & -0.011 & 0.048 & -0.049 \\
\hline $70+$ & -0.042 & $-0.085^{*}$ & -0.041 & $-0.124 * * *$ \\
\hline Graduates & $0.106^{* * *}$ & $0.050^{* *}$ & 0.024 & 0.000 \\
\hline \multicolumn{5}{|l|}{ Household income quartile } \\
\hline 2nd quartile & -0.045 & -0.022 & -0.027 & $-0.101 * * *$ \\
\hline 3rd quartile & -0.045 & -0.023 & $-0.051^{*}$ & $-0.148 * * *$ \\
\hline 4th quartile & -0.063 & -0.039 & $-0.077 * *$ & $-0.211 * * *$ \\
\hline Self-employed & -0.026 & -0.028 & -0.020 & -0.067 \\
\hline Financial assets & 0.0001 & -0.0001 & 0.00002 & -0.00004 \\
\hline Housing and properties & 0.0003 & 0.0001 & -0.0004 & $-0.001 *$ \\
\hline Experience of unemployment & 0.013 & -0.001 & 0.013 & $0.049^{*}$ \\
\hline Expectation of unemployment & $0.060^{* *}$ & $0.056^{* *}$ & $0.081^{* * *}$ & 0.023 \\
\hline Rate of consumption growth (\%) & 0.001 & $0.006^{* *}$ & $0.012 * * *$ & $0.009 * * *$ \\
\hline Rate of income growth (\%) & $0.006^{*}$ & 0.003 & -0.003 & 0.002 \\
\hline $\begin{array}{l}\text { Risk-aversion index: } \\
\text { 1- chance of rain (\%) / } 100\end{array}$ & -0.009 & 0.006 & 0.049 & $0.089^{* *}$ \\
\hline Altruistic (willing to donate) & $0.055^{* *}$ & $0.079 * * *$ & $0.114 * * *$ & $0.064 * *$ \\
\hline Observations & 2014 & 2010 & 1976 & 2013 \\
\hline Psudo R2 & 0.02 & 0.01 & 0.04 & 0.04 \\
\hline Log likelihood & -1352.08 & -1326.87 & -1072.03 & -1333.51 \\
\hline
\end{tabular}

Note: * significant at $10 \% ; * *$ significant at $5 \% ; * * *$ significant at $1 \%$ 